\title{
Delineating priority areas for marine biodiversity conservation in the Coral Triangle
}

Irawan Asaad ${ }^{1,2^{*}}$, Carolyn J. Lundquist ${ }^{1,3}$, Mark V. Erdmann ${ }^{4}$, Mark J. Costello ${ }^{1}$

\author{
${ }^{1}$ Institute of Marine Science, University of Auckland, Auckland, New Zealand \\ ${ }^{2}$ Ministry of Environment and Forestry, Jakarta, Indonesia \\ ${ }^{3}$ National Institute of Water \& Atmospheric Research, Hamilton, New Zealand \\ ${ }^{4}$ Conservation International-Asia Pacific Marine Programs, Auckland, New Zealand
}

Corresponding email: 1. asaad@auckland.ac.nz. 


\title{
Delineating priority areas for marine biodiversity conservation in the Coral Triangle
}

Keywords: Biodiversity conservation, Ecological criteria, Marine protected area, Multi-criteria analysis, Coral Triangle

Content: 321 words abstract. Main text 7,088 words. 5 figures. 6 tables. Supplementary materials.

\section{Highlights}

1. We prioritized areas for marine conservation in the Coral Triangle region.

2. The data used were species' ranges, occurrence records, habitat richness, threatened species, and sea turtle nesting sites.

3. Nearly $13 \%$ of the Coral Triangle was clustered into areas of high biodiversity importance.

4. The highest priority sites were the northern tip of Sulawesi, Ambon, Kei Islands, and Raja Ampat Archipelago in Indonesia; and

5. Verde Island Passage, and the southern part of Negros and Cebu Islands, in the Philippines.

\begin{abstract}
Identifying priority areas for biodiversity conservation requires systematic approaches and integrated ecological and biological information. Here, we applied a range of ecological criteria to assess areas of biodiversity importance in the Coral Triangle region, a priority region for marine biodiversity conservation because of its high species richness and endemicity. We used distribution data of three biogenic habitats to assess the criterion of sensitive habitat, modeled geographic distributions of 10,672 species ranges and occurrence records of 19,251 species to evaluate the criterion of species richness, distributions of 834 species of special conservation concern to examine the criterion of species of conservation concern, distributions of 373 reef fish species to assess the criterion of restricted-range species, and distribution of nesting sites and migratory route of six species of sea turtle to evaluate the criterion of areas of importance for particular life history stages. We identified areas of biodiversity importance by superimposing each of the different criterion. We performed two tiers of multicriteria analysis: (1) a Coral Triangle regional level analysis to identify "clustered hotspots" (i.e., groups of cells) of biodiversity significance, and (2) a site-based analysis to identify the specific sites (cells) of greatest biodiversity importance. We found that approximately $13 \%$ of the Coral Triangle was clustered into hotspots of high biodiversity importance. These areas occurred along the southern part of the Philippines, the north-eastern part of Malaysian Sabah, central to eastern reaches of Indonesia, the eastern part of Papua New Guinea and the Solomon Islands. By comparison, the site-based analysis identified seven sites of highest biodiversity importance in the Coral Triangle include: (1) the northern tip of Sulawesi Island, (2) Ambon Island, (3) Kei Islands, (4) Raja Ampat Archipelago of Indonesian Papua, (5) the Verde Island Passage, (6) the southern part of Negros Island, and (7) Cebu Island. This information is useful to inform participatory decision-making processes in the Coral Triangle region to identify priority areas for conservation and management.
\end{abstract}

\section{Introduction}

Protected areas have been widely advocated as an effective tool for conserving and managing biodiversity (Brooks, 2010; Venter et al., 2014). Marine protected areas (MPA) benefit conservation of species and habitat (Beger et al., 2003; Williams et al., 2009; Hart et al., 2013; Péron et al., 2013), fisheries management (e.g. increased abundance, species diversity and "spill over" effect) (Russ \& Alcala, 2010; Hamilton et al., 2011; Edgar et al., 2014; Smith et al., 2014), and recreational and educational opportunities (Ballantine, 2014; Costello, 2014). Coral reef cover inside Indo-Pacific MPA has shown increases up to 2\% per year (Selig \& Bruno, 2010), while globally, biomass of large fishes was 35\% greater inside compared to outside MPAs (Edgar et al., 2014). Currently, over 12 million $\mathrm{km}^{2}$ of the world's ocean has been designated as MPAs (Juffe-Bignoli et al., 2014), with a growth of over 360-fold in the last ten years (Klein et al., 2015). However, the proportion of MPA that actually conserve biodiversity is questionable. Around $94 \%$ of MPA are "take-MPA" that allow fishing within their boundaries and cannot protect all aspects of biodiversity (Costello \& Ballantine, 2015). More than $83 \%$ of marine species have less than $10 \%$ of their home ranges protected within MPAs globally (Jenkins \& Van Houtan, 2016). Thus, to support the MPA's objectives in conserving biodiversity requires additional designation of larger, more effective and fully protected areas through identification of important areas for biodiversity conservation (Ricketts et al., 2005; Butchart et al., 2015).

Previously, we synthesized a set of ecological and biological criteria to aid systematic selection of areas for biodiversity conservation (Asaad et al., 2016). Based on the review of 15 international initiatives, we identified eight ecological and biological criteria required to identify suitable locations for biodiversity conservation. Four criteria identified areas that contain (1) unique and rare habitats; (2) fragile and sensitive habitats; (3) habitats 
important for ecological integrity; and (4) a network that is representative of all habitats. Another four criteria were based on species-specific attributes, including (5) the presence of species of conservation concern; (6) the occurrence of restricted-range species; (7) areas containing high species richness; and (8) areas important for life-history stages of particular species. Here, we explored the application of these synthesized ecological criteria in performing an assessment of important areas for marine biodiversity conservation in the Coral Triangle region.

The Coral Triangle (CT) Region is situated along the equator between the Indian and Pacific Oceans. This region includes the Exclusive Economic Zone of six countries (Indonesia, Malaysia, The Philippines, Papua New Guinea, Timor-Leste, and Solomon Islands) (Fig.1). It is a global hotspot of marine biodiversity, and contains more than $76 \%$ of the world's shallow-water reef-building coral species (Veron et al., 2009), 37\% of the world's reef fishes (Allen, 2008), 50\% of razor clams (Saeedi et al., 2016), six out of seven of the world's sea turtles and the largest mangrove forest in the world (Polidoro et al., 2010; Walton et al., 2014). In the socioeconomic context, the marine ecosystems in this region have a gross domestic product worth $\$ 1.2$ trillion per year (Asian Development Bank, 2014), and more than 120 million people benefit directly from its ecosystem goods and services (Foale et al., 2013). However, the resources within this region are being threatened by anthropogenic activities and climate change induced impacts (Hoegh-Guldberg et al., 2009; Burke et al., 2012; McLeod et al., 2012). In response, in 2007 the Coral Triangle countries declared their commitment to working collaboratively to conserve and sustainably manage their coastal and marine resources through a multilateral partnership called the Coral Triangle Initiative on Coral Reefs, Fisheries and Food Security (CTI-CFF) (CTICFF, 2009, 2013). One of the objectives of this initiative is to establish effective networks of MPAs, by protecting a representative range of biodiversity features (Weeks et al., 2014), encompassing the temporal and spatial scale of ecological systems (Laffoley et al., 2008) and facilitating ecological linkages between protected sites (Green et al., 2014). Currently, there are almost 2,000 MPAs within this region, covering an area of $200,881 \mathrm{~km}^{2}$ (White et al., 2014), which is less than $4 \%$ of the marine area in this region. Moreover, underrepresentation of ecological and biodiversity coverage, and lack of management effectiveness (Weeks et al., 2014; White et al., 2014) are among factors that prevent MPAs within this region from achieving their goals (White et al., 2014). There is thus great interest to overcome the current limitations of MPA coverage and to develop conservation priorities for the protection of biodiversity and ecosystem services in the region (Green et al., 2014; Beger et al., 2015).

Previous biodiversity conservation studies in the Coral Triangle provided insights on MPA development (Green et al., 2009; Green et al., 2014), biodiversity patterns (Hoeksema, 2007; Allen, 2008) and conservation priorities (Ambal et al., 2012; Huffard et al., 2012; Beger et al., 2015) (Table 1). However, those studies were limited to specific taxonomic groups, had restricted geographic scope, and/or were based on limited datasets. The framework to design MPAs proposed by Green et al. (2014) was applied at a region-wide scale but has not been used to identify MPAs at national or local scales (Walton et al., 2014). The prioritization analysis developed by Beger et al. (2015) was successful in identifying areas of high conservation value but included only limited information on species connectivity models and insufficient data on threatened species. In other studies, conservation priorities were exclusively applied at national scales, such as the identification of key biodiversity areas in the Philippines (Ambal et al., 2012), and geographic priorities for biodiversity conservation in Indonesia (Huffard et al., 2012). Here, we identify areas of importance for biodiversity conservation at the regional scale for the Coral Triangle, based on a comprehensive measurement of biodiversity, encompassing a wide-variety of taxonomic groups, and pre-defined systematic ecological criteria.

We examined the applicability of the ecological criteria recommended in Asaad et al. (2016) to delineate areas of biodiversity importance. We applied biodiversity informatics to retrieve and analyze data on habitat and species diversity, and species distributions of multiple taxonomic groups. We developed a multi-criteria analysis and performed two tiers of analysis: (1) Regional-level analyses to identify "clustered hotspots" of biodiversity significance, and (2) Site-based analyses to identify specific sites of the highest importance for biodiversity protection. This research provides a baseline describing the intrinsic biological and ecological value of the region that benefits governments, NGO's and decision makers in the identification of priority areas for conservation.

\section{Methods}

\subsection{Study Area}

The study area centered on the Coral Triangle countries and their surrounding marine areas, with the bounding coordinates extending from $90^{\circ} \mathrm{E}$ to $175^{\circ} \mathrm{E}$ and $23^{\circ} \mathrm{N}$ to $16^{\circ} \mathrm{S}$ (Fig. 1). We acknowledge that other scientists 
have proposed different scientific and ecological boundaries for the Coral Triangle (e.g., Green \& Mous, 2008; Veron et al., 2009; and reviewed in Hoeksema, 2007). Here we use the boundary as defined by the Coral Triangle Initiative which has declared its implementation boundary to include the full exclusive economic zones (EEZs) of Indonesia, Malaysia, Papua New Guinea, the Philippines, Solomon Islands, and Timor-Leste, and includes the EEZs of two adjacent nations: Brunei Darussalam and Singapore.

Here, the terminology of "Coral Triangle Region" refers to the area covered by the bounding geographical coordinates of the study area, while the term "Coral Triangle Countries" refers to the six countries (i.e., Indonesia, Malaysia, The Philippines, Papua New Guinea, Timor-Leste, and Solomon Islands) that are the signatories of the Coral Triangle Initiatives Declarations. The analysis was extended to the periphery of the Coral Triangle countries to have a comprehensive measurement of biodiversity in the region.

\subsection{Data}

We explored the application of five ecological criteria recommended by Asaad et al. (2016) for which data were readily available. We used distribution data for three biogenic habitats (coral reefs, seagrass meadows, and mangrove forests) to assess the criterion of sensitive habitat, collated from global summary reports for each habitat type (Table 2). All of these habitat datasets were referenced to a geographic coordinate system of WGS84 (World Geodetic Survey 1984) and a standardized metadata system developed by UNEP-WCMC (Weatherdon et al., 2015).

To assess the criterion of potential species richness, we used modeled geographic species ranges extracted from AquaMaps (Kaschner et al., 2016) (Table 2). AquaMaps generates a prediction of relative probabilities of species range at a resolution of half-degree cells. Each cell contains a probability value ranging from 0 and 1 , representing the relative suitability of that cell for the specified species. In this analysis, we assumed a species range included in cells where their probability of occurrence values was greater than 0.5 . In addition, we used species point occurrence records from the Ocean Biogeographic Information System (OBIS) (OBIS, 2015) (Table 2) to complement the AquaMaps species range data (Supplementary Table S1). The taxonomic differences between datasets were resolved because OBIS uses the World Register of Marine Species (WoRMS) database (Horton et al., 2016) for species nomenclature and classification. Species names in AquaMaps are also regularly synchronized with the WoRMS database.

To assess the criterion of the occurrence of species of conservation concern, we extracted occurrence records of five classes (i.e., bony fishes, anthozoans, elasmobranchs, mammals, and molluscs) from OBIS (OBIS, 2015) and FishBase (Froese \& Pauly, 2016) (Table 2). We selected these taxa to represent a diversity of threatened taxa and excluded seabirds from our analysis, as most are migratory or wide-ranging. We included species of conservation concern as recognised by IUCN Red List categories (IUCN, 2015), CITES (UNEP-WCMC, 2015) and national directives of the Coral Triangle countries. A species was assigned as a species of conservation concern if it was categorized as either (1) Critically Endangered (CR), Endangered (EN) or Vulnerable (VU) according to the IUCN Red List of Threatened Species, or (2) listed in Appendix 1 or Appendix 2 of CITES as species that need a greater level of protection from over-harvesting, or (3) classified as threatened or protected based on national regulations. Appendix I of CITES includes species that are threatened with extinction, and Appendix II includes species that, although currently not threatened with extinction, may become so without trade controls. For the national regulations, we used the list of protected species enacted by the governments of Indonesia (Government Regulation, 1999), Malaysia (Fisheries Act, 1985; Fisheries Regulation, 1999), and the Philippines (Republic Act, 2001) (Supplementary Table S2). The assessment using different scales of conservation concern (global to national) was designed to account for a large number of species that may be vulnerable to human activities.

The criterion of restricted-range species was assessed using the distributions of 373 reef fishes (comprising 150 genera and 47 families) that are each endemic to the Coral Triangle (Table 2). These data were extracted from a dataset of nearly 4,000 species of Indo-Pacific reef fishes (Allen, 2008; Allen \& Erdmann, 2013). Here, restricted-range is defined as a reef fish species with a spatial distribution of less than 5 million $\mathrm{km}^{2}$ and whose known range is only within the Coral Triangle. For consistency, throughout the rest of this paper, these Coral Triangle restricted-range reef fishes will be referred to simply as "restricted-range reef fishes". We also note that these datasets define reef fishes as fish species that live on shallow water coral reefs and associated substrata (i.e., sand or rubble patches, seagrass beds, etc.) less than $60 \mathrm{~m}$ deep (Supplementary Table S3).

We used sea turtle nesting habitat and migratory routes as indicators of important areas for sea turtles. Six sea turtle species inhabit the Coral Triangle: green, leatherback, loggerhead, hawksbill, olive Ridley and flatback 
turtles. A total of 2,055 point occurrence records of sea turtles were retrieved from OBIS (OBIS, 2015) and Indonesian sea turtle datasets (MoF-MoMAF, 2010) (Table 2). Over 16\% of the records were turtle nesting sites (Supplementary Table S4).

We extracted data on 16 environmental variables from the Global Marine Environment Datasets (GMED) (Basher et al., 2014), i.e., depth, slope, land distance, temperature, surface current, salinity, wind speed, tide, primary productivity, photosynthetically active radiation (PAR), chlorophyll-a, $\mathrm{pH}$, dissolved oxygen, nitrate, silicate, and calcite. These environmental layers were in an ASCII format at a spatial resolution of 5-arc min $\left(0.083^{\circ}\right.$ grid cells, c. $9 \mathrm{~km}^{2}$ at the equator) (Supplementary Table S5).

\subsection{Data Analysis}

We identified areas of biodiversity importance by superimposing each of the different information layers (Malczewski, 2006; Greene et al., 2011; Bottero et al., 2013). We explored the application of the ecological criteria and two tiers of multi-criteria analysis: a Coral Triangle regional level analysis to identify "clustered hotspots" (i.e., groups of cells) of biodiversity significance, and a site-based analysis to identify the specific sites (cells) of greatest biodiversity importance. An individual "site" was defined as a single half-degree cell.

All datasets were clipped to the Coral Triangle region using a grid approach of half-degree cells $\left(0.5^{\circ}\right)$ using the c-squares geocodes system developed by Rees (2003). C-squares divide the world's surface to a grid square to enable simple spatial queries. Using this approach, all of the datasets were presented and mapped in a regular shape of a grid square. The Coral Triangle region comprised 13,360 cells, where each cell covered an area of 55 x $55 \mathrm{~km}$. All of the spatial analyses were performed using ArcGIS ver. 10.5 (ESRI, 2016a). For the biogenic habitat coverage, we classified and scored the cells based on the total number of habitats that fell within each cell, i.e., 1,2 , or 3 .

Species richness was determined based on (i) species ranges derived from modelled geographic distributions and (ii) species occurrence records. For the species ranges, richness was based on the number of predicted species in each cell. Within the study area, the number of species per $0.5^{\circ}$ cells ranged from 0 to 5,509 . Thus, we classified the cells into five equal interval classes based on the total number of species that fell within each cell, i.e, class 1 ( 1 - 1,101 species); class 2 (1,102 - 2,203 species); class 3 (2,204 - 3,305 species); class 4 (3,306 4,407 species); and class 5 (4,408 - 5,509 species). An equal interval classification was chosen to allow an unbiased comparison across criteria.

For the species occurrence records, we calculated $\mathrm{ES}_{50}$ (estimated species in random 50 samples) based on Hulbert's index of expected species richness (Hurlbert, 1971) and Hulbert's standard errors (Heck et al., 1975) using the Vegan package in R v3.2.2 (R Core Team, 2016). We used the Hurlbert index rather than simple species richness indices or the number of species present in a designated area, as it is based on a rarefaction technique (Sanders, 1968) that allows for comparison of species numbers between communities and is less dependent on sample size (Boyle et al., 1990; Reiss \& Kröncke, 2005). We then classified the cells into five equal interval classes, i.e., class $1\left(\mathrm{ES}_{50} 1\right.$ - 10); class 2 (11 - 20); class 3 (21 - 30); class 4 (31 - 40); and class 5 (41-50).

We evaluated the distribution of species of conservation concern based on species occurrence records. A similar approach to the species richness analysis was applied but at a lower sample size to account for fewer species' records per cell. A Hulbert index with $\mathrm{ES}_{35}$ (estimated species in random 35 samples) was used to identify cells with the highest richness of species of conservation concern. We then classified the cells into five equal interval classes, i.e., class 1 ( $\mathrm{ES}_{35} 1$ - 6); class 2 (7 - 13); class 3 (14 - 20); class 4 (21 - 27); and class 5 (28 - 35).

We assigned the distribution of restricted-range reef fishes to $0.5^{\circ}$ grid cells. We scored each cell based on the total number of restricted-range reef fishes that fell within each cell. The value ranged from 0 to 101 species. We classified the cells into five equal interval classes, i.e., class 1 ( $1-20$ species); class 2 ( $21-40$ species); class 3 (41 - 60 species); class 4 (61 - 80 species); and class 5 (81 - 101 species).

For the important sea turtle areas, we classified and scored the cells based on the total number of sea turtle species with important areas within each cell, i.e., 1, 2, or 3. No cells had more than three species of turtle present. 
We used a non-parametric Spearman's rank correlation coefficient analysis in IBM SPSS Statistics v.23 to assess the strength of the statistical relationships between each criterion, and between each criterion and the 16 aforementioned environmental variables.

All of the datasets obtained from each criterion were superimposed to produce an integrated dataset. All criteria were weighted equally. The areas of biodiversity importance were analysed based on the biodiversity score of each cell. The score was assessed based on the unweighted sum of criteria for each cell. This integrated dataset along with the associated biodiversity scores is the basis for the regional-level and site-based analyses of areas important for biodiversity.

We conducted the regional-level analysis by evaluating clustered areas of biodiversity importance using the hotspots analysis tool in ArcGIS 10.5. The hotspot tool identifies the spatial patterns of data based on the GetisOrd GI* statistics (ESRI, 2016b; Getis \& Ord, 1992; Ord \& Getis, 1995), such that geographic cells with high scores or cells with low scores tend to be clustered together. The statistically significant Z score (GI* statistics) was analyzed by comparing the local sum of a cell's score and its neighbors proportionally to the sum of all cells' scores. For statistically significant positive $\mathrm{Z}$ scores, the larger the $\mathrm{Z}$ score, the more intense the clustering of high scores (hotspots). For statistically significant negative $\mathrm{Z}$ scores, the smaller the $\mathrm{Z}$ score, the more intense the clustering of low scores (coldspots). The hotspots analysis produced three classes of hotspots $(99 \%, 95 \%$ and $90 \%$ confidence level), three classes of cold spots $(99 \%, 95 \%$ and $90 \%$ confidence level) and one class of not statistically significant clusters. Based on this analysis we developed a map of "hotspot clusters" of cells of biodiversity importance in the Coral Triangle.

While the hotspots analysis identified clustered areas of biodiversity importance, the site-based analysis identified specific sites of highest biodiversity importance by analyzing the biodiversity score of each cell. For the purposes of this analysis, a site was defined as a given half-degree cell. The score for each cell ranged from 0 - 22. The higher the score, the higher the cell's biodiversity importance. We ranked the cells into five equal interval classes. Based on this analysis, we developed a map of areas of biodiversity importance in the Coral Triangle.

\section{Results}

\subsection{Application of ecological criteria in selecting areas important for biodiversity conservation}

\subsubsection{Sensitive habitat}

The largest coverage of biogenic habitat in the Coral Triangle (CT) was coral reefs (14\%), followed by mangrove forests $(12 \%)$ and seagrass meadows (3\%). These habitats were distributed in more than $18 \%$ of the CT areas. Of these, more than $51 \%$ of individual $0.5^{\circ}$ cells were occupied by one habitat, $40 \%$ by two different habitats and only $9 \%$ by three biogenic habitats. The combination of coral reefs and mangroves dominated the biogenic habitat areas by $35 \%$. In contrast, only $1 \%$ of the area was occupied only by seagrass meadows.

Areas with all three biogenic habitats occurred in the southern part of Luzon Island, northern part of Mindanao Island of the Philippines, southern tip of the Malaysian Peninsula, western part of Java Island, northern part of Sulawesi Island, the Moluccas Islands, Raja Ampat Archipelago of Indonesian Papua, and southern part of the Makira Province in the Solomon Islands (Fig. 2a).

\subsubsection{Species Richness}

\section{a. Species ranges from AquaMaps}

The classes of bony fishes and crustaceans were distributed in more than $90 \%$ of the Coral Triangle, while chimaerans were recorded from only $17 \%$ of the region. Bony fishes had the largest number of species per-cells (3,329 species), followed by molluscs ( 950 species) and crustaceans (458 species) (Table 3 ). These relative numbers reflect the inclusion of these taxa in AquaMaps rather than their relative occurrence in the region.

More than $42 \%$ of species had a relatively small range (i.e., distributed across less than $10 \%$ of the Coral Triangle). There were six species (less than $1 \%$ of total species) distributed over $90 \%$ of the Coral Triangle areas (e.g., Cypselurus angusticeps, narrowhead flyingfish; Cypselurus naresii, pharao flyingfish; Coryphaena hippurus, mahi mahi; Kajikia audax, striped marlin; Katsuwonus pelamis, skipjack tuna; and Thunnus albacares, yellowfin tuna). 

Analysis of the overlap of the predicted geographic ranges of species demonstrated that $70 \%$ of the Coral richness areas. A small proportion of cells $(6 \%)$ was predicted to be inhabited by more than 4,408 species, thus these cells were classified as highest species richness areas. These highest richness areas were identified along the coast of the Philippines (northern part of Luzon, Sullivan Sea, Bohol, Mindanao, Palawan and Sulu Archipelago), Malaysia (north-eastern part of Sabah), Indonesia (northern and south-eastern part of Sulawesi, Banda Sea, Mollucas, Raja Ampat Archipelago of Papua), Papua New Guinea (coastal area of Madang, New Britain, Milne Bay, Louisiade Archipelago, and Bougainville Island), and Solomon Islands (Guadalcanal Island and Makira Province) (Fig. 2b).

\section{b. Species occurrence from OBIS}

The number of species occurrence records was significantly correlated with the number of species, and species richness was not at an asymptotic level for our data (Supplementary Figure S1a). The maximum number of species in one cell was 3,298 species, and the maximum occurrence was 14,013 records. There were 2,261 cells $(17 \%)$ that contained only one species and 1,785 cells $(13 \%)$ that contained only one occurrence record.

Based on the analysis of the index of expected species richness $\left(\mathrm{ES}_{50}\right)$, only $4 \%$ of the Coral Triangle had an index $>40$. We classified these areas as the highest species richness areas in the Coral Triangle. These areas were identified in the Philippines (southern part of Luzon, Mindoro, Cebu, Bohol Island, Sulu Archipelago), Malaysia (Semporna peninsula - Sabah), Indonesia (northern and southern part of Sulawesi, eastern part of Bali, Moluccas, Raja Ampat Archipelago), Papua New Guinea (coastal area of Madang, western part of Papua Island), Solomon Islands (Guadalcanal Island and Makira Province), northern part of Australia and southern part of the Andaman Islands (Fig. 2c).

\subsubsection{Species of conservation concern}

In total, there were 834 marine species categorized as species of conservation concern in the Coral Triangle. The largest number were the anthozoans (707 species), followed by elasmobranchs (73 species), mammals (29 species), bony fishes (19 species), and molluscs (6 species) (Tables 4 and S2).

Based on the IUCN Red List criteria, these species of conservation concern included those that are categorized as Vulnerable (167 species), Endangered (17 species) and Critically Endangered species (6 species). All of the Critically Endangered species were elasmobranchs (i.e., Glyphis gangeticus, Pristis pectinata, Carcharhinus hemiodon, Pristis zijsron, Glyphis siamensis, and Pristis pristis) (Table 4 and S2). Nine mammals and seven elasmobranchs were listed in the CITES Appendix I, and 757 species in Appendix II (Table 4 and S2). All of the anthozoans (particularly hard reef coral species) and bony fishes were listed in CITES Appendix II. According to the regulations of the governments of Indonesia, Malaysia or the Philippines, there were 23 marine mammal species, 11 anthozoans, and 10 molluscs that were categorized as protected species (Tables 4 and S2).

The distribution pattern of the species of conservation concern had a linear correlation with the number of species and the number of occurrence records from OBIS. The maximum number of species in one cell was 298 species, and the maximum occurrence record was 3,665 records. There were 1,740 cells (13\%) that contained only one species and 1,250 cells (10\%) that contained only one occurrence record of species of conservation concern (Fig. S1b).

Nearly $19 \%$ of the Coral Triangle was inhabited by a least one species of conservation concern. The largest percentage of the areas $(17 \%)$ were classified as low species richness $\left(\mathrm{ES}_{35} 1-6\right)$. Less than $1 \%$ of the total area had the highest index $\left(\mathrm{ES}_{35}>29\right)$ and classified as the highest species richness areas for species of conservation concern. These areas included the Spermonde Islands of Indonesia, the northern part of the Australian Great Barrier Reef, the southern part of the Andaman Islands, and the northern part of the Marshall Islands. However, the last three areas were situated outside of the jurisdiction of Coral Triangle countries (Fig. 2d).

\subsubsection{Restricted-range reef fishes}

A total of 373 restricted-range reef fishes were investigated to identify areas important for biodiversity conservation in the Coral Triangle. The largest percentage of these restricted-range reef fishes originated from three families; i.e., Gobiidae (17\%), Pseudochromidae (10\%) and Blenniidae (8\%) (Supplementary Table S3). 
Five endemic species had extremely small known distributions $\left(<100 \mathrm{~km}^{2}\right)$ : Pseudanthias mica, Paracheilinus alfiani, Pentapodus komodoensis, Callionymus madangensis, and Enneapterygius sp 1. The first three species were restricted to Indonesian waters, while the last two species were found only in Papua New Guinea. Pseudanthias mica was considered as the most restricted-range reef fish species, with a known distribution of only $11.3 \mathrm{~km}^{2}$. In contrast, five species (Ostorhinchus neotes, Trimma rubromaculatum, Trimma haimassum, Halichoeres binotopsis and Siokunichthys nigrolineatus) had comparatively large distributional ranges ( $>4$ million $\mathrm{km}^{2}$ ), though obviously still considered restricted compared to many reef fish species with broad IndoPacific ranges. The largest of our restricted ranges was that of Ostorhinchus neotes at approximately 4.8 million $\mathrm{km}^{2}$ (Fig. S2).

In total, $20 \%$ of the area in the Coral Triangle was inhabited by restricted-range reef fishes. Of these areas, $7 \%$ were categorized as low endemic species richness areas, where the total number of restricted-range reef fishes present ranged from 1 to 20 species. A small fraction of the Coral Triangle was classified as high endemic species richness areas and was inhabited by more than 60 restricted-range reef fishes. These areas were found in the southern part of Mindoro of the Philippines, the northern part of the Sulawesi Island, the Raja Ampat Archipelago, Seram Island, Bali Island and the coastal area along the Nusa Tenggara Islands of Indonesia. The largest occurrence of restricted-range reef fishes, with over 80 species present, was identified at two sites, the northern tip of Sulawesi and Raja Ampat Archipelago (Fig. 2e).

\subsubsection{Areas important for life history stages}

The largest percentage of reported turtle nesting sites in the study area were inhabited by green turtles (32\%), while migratory route data were dominated by leatherback turtles (52\%) (Supplementary Fig. S3 and Table S4). Based on their distribution, nearly $19 \%$ of the Coral Triangle was important for sea turtles. The largest percentage of these areas were inhabited by one turtle species (18\%). Less than $0.2 \%$ of the areas contained areas important to three turtle species and were considered as the most important sea turtle areas. These areas were identified along the southern part of Sumatera Island, the north-eastern part of the Malaysian peninsula, the southern part of Java Island, the southern part of the Philippines and several marine national parks in Indonesia (i.e., Taka Bonerate, Bunaken, Wakatobi, Teluk Cenderawasih) (Fig. 2f).

\subsubsection{Correlation between criteria}

All comparisons had a positive correlation (Table 5 and Fig. 3). There was a strong positive correlation between the criterion of biogenic habitat and species ranges $(r=0.57)$, and the criterion of species ranges and restrictedrange reef fishes $(r=0.49)$.

A positive correlation was identified between all criteria with environmental variables of depth, primary productivity, mean chlorophyll-a, and silicate. The highest positive correlation coefficients were identified between the criterion of biogenic habitat and depth $(r=0.44)$, species ranges and primary productivity $(r=0.71)$, species occurrence and depth $(r=0.21)$, species of conservation concern and primary productivity $(r=0.31)$, restricted-range reef fishes and primary productivity $(r=0.30)$, areas important for sea turtles and sea-surface temperature $(r=0.22)$ (Table 6).

\subsection{Integration of ecological criteria in selecting priority areas for biodiversity conservation}

Nearly $13 \%$ of the Coral Triangle was clustered into biodiversity hotspots based on the criteria analyzed. Of these, $2 \%$ were considered as hotspots with a $90 \%$ confidence level $\left(Z_{\max }=1.8\right), 3 \%$ with a $95 \%$ confidence level $\left(Z_{\max }=2.5\right)$ and $8 \%$ with a $99 \%$ confidence level $\left(Z_{\max }=8.4\right)$. The latter were classified as the highest biodiversity hotspots cluster and included the ecoregion of eastern Philippines, Palawan/North Borneo, Makassar Strait, Halmahera, the Bird's Head region of Indonesian Papua, Lesser Sunda Islands, Banda Sea, north-eastern part of the Papua New Guinea and the Solomon Sea (Fig. 4).

Our site-based evaluation identified seven sites as the most important areas for marine biodiversity conservation in the Coral Triangle, include three sites in the Philippines (i.e., the Verde Island Passage, the southern part of Negros Island and Cebu Island) and four sites in Indonesia (i.e., the northern tip of Sulawesi, Ambon Island, Kei Islands, and Raja Ampat Archipelago) (Fig. 5). 


\subsection{Application of ecological and biological criteria}

The three biogenic habitats, i.e., coral reefs, seagrass, and mangroves, occurred in over $18 \%$ of the cells covering the Coral Triangle region. Of these, nearly $9 \%$ were inhabited by all three habitats and are considered as the highest priority areas. Unfortunately, almost all of these habitats are at risk due to proximity to densely populated areas and have experienced a decline in coverage and/or quality. More than $85 \%$ of the coral reefs in the Coral Triangle are threatened by anthropogenic pressure (Burke et al., 2012). Due to habitat conversion, mangrove forests have been reduced by $30 \%$ since 1980 (Polidoro et al., 2010) and seagrass habitats by more than 50\% (Unsworth \& Cullen, 2010). Thus, incorporating data on sensitive habitats, and subsequently identifying significant biodiversity areas based on those habitats, is an important starting point to facilitate a conservation prioritization for the region.

Knowledge is far less complete with respect to the remaining marine habitats in the Coral Triangle region. These include deep water coral reefs (Roberts et al., 2006), beaches, mudflats, rocky intertidal zones and other subtidal habitats. A European biotope classification system provides a framework and procedure to use bathymetry, substrata and a number of other sub-categories including fauna and flora to map habitats (Costello \& Emblow 2005, JNCC, 2015). In addition, data on ocean currents, nutrients, temperature and other variables are now available (e.g., GMED (Basher et al., 2014); EMU (Ecological Marine Units) (ESRI, 2016c); and MSEC (Marine Socio-Environmental Covariates) (Yeager et al., 2017)) to map potential pelagic habitats and conditions (e.g., current exposure) that influence benthic biotopes. Further surveys are needed to assess the conservation priorities for other intertidal, subtidal, and deep-sea habitats, which, due to data limitations, were not analysed in the present study.

Species richness is the most popular index to quantify biological diversity (Costello et al., 2004). The biological diversity of the Coral Triangle was explored using both species ranges and species occurrence records. The first dataset is prone to commission errors (false positives) (Jetz et al., 2008) and the latter dataset by omission errors (false negatives) (Langhammer et al., 2007). These types of species diversity analyses are generally justified as being 'best available data', as the availability of complete species distribution data is quite rare (Klein et al., 2015; Jenkins \& Van Houtan, 2016), especially in the ocean (Costello et al., 2015). Based on the modeled species ranges, about $6 \%$ of the Coral Triangle was identified as areas with the highest species richness. These areas were predicted to be occupied by more than 4,000 species and identified along the center of the Coral Triangle, from the southern part of Philippines to the Wallacean region of Indonesia (the area between the Sunda and the Sahul shelves). In parallel, about $4 \%$ of the Coral Triangle was identified as the most species-rich areas based on species occurrence records. Nearly $20 \%$ of these areas overlapped with the high species richness areas that were identified using the modeled distributions of species ranges. Previous research found similar species distribution patterns for reef corals (Veron et al., 2009; Waheed \& Hoeksema, 2013) and reef fishes (Allen, 2008) as those identified by both species richness metrics in this analysis.

A total of 834 species were identified as species of conservation concern in the Coral Triangle. These species were distributed across nearly $19 \%$ of the Coral Triangle. Of these areas, less than $1 \%$ were considered as the highest priority areas. Unfortunately, the threats to these species are likely to increase (Polidoro et al., 2009). Chondrichthyan species (i.e., sharks, rays and chimaeras) are threatened by fisheries activities, including accidental catch and habitat destruction (Stevens et al., 2005). In the Coral Triangle, shark fisheries increased during the last decade due to growing demand for shark products (Lack \& Sant, 2011; Lack \& Sant, 2012), and two countries (Indonesia and Malaysia) are consistently listed within the top ten shark catching countries globally (Food and Agricultural Organization, 2012). In Papua New Guinea, several threatened chondrichthyan populations have been declining due to pollution from mining industry tailings (White \& Kyne, 2010). Thus, identifying areas inhabited by species of conservation concern is essential in prioritizing management efforts to reduce such threats. In addition, areas which are inhabited by a large number of species of conservation concern may be indicative of a lack of disturbance and should therefore be considered for prioritization for gazetting within MPAs. However, because all the data used here is historic the present results reflect past species ranges and occurrences. Whether the threatened species still occur in these locations requires confirmation and monitoring.

The criterion of restricted-range species was analyzed using the distribution of 373 species of regionally endemic reef fishes. The Raja Ampat Archipelago in Indonesia was identified as the epicenter of restrictedrange reef fishes, with over 100 species of Coral Triangle endemic reef fishes occurring within its borders. This high endemicity of reef fishes is concordant with an extremely high diversity of reef coral species (over 600 species) (Veron et al., 2009; Mangubhai et al., 2012). Several factors that may contribute to this high local 
endemism include (i) the high level of habitat diversity, due to its location as a biogeographic crossroads of Indonesia, Micronesia and the Arafura Sea (Allen \& Erdmann, 2009), and (ii) the complexity of the geological history of the region, due to drifting and colliding tectonic plates, shifting shorelines, and fluctuating sea-levels (Polhemus, 2007).

Of the six species of sea turtles inhabiting the region, green and hawksbill turtles were the most abundant and widespread. Major sea turtle nesting beaches were found along the coasts and small islands of the Coral Triangle, notably the Banyak Islands, Berau, Paloh, Pangumbahan, Derawan, and Sukamade in Indonesia (MoFMoMAF, 2010), Tawi-Tawi region in the Philippines, and Turtle Island both in the Philippines and Malaysia (MWWP, 2014). Other important nesting sites include Jamursba Medi and Warmon beaches in the Bird's Head region of Indonesian Papua, which are considered as one of the most significant rookeries for leatherback turtles in the Pacific (Hitipeuw et al., 2007; Mangubhai et al., 2012). Most of the areas that were identified as highly important areas for sea turtles were major nesting sites, which were experiencing a trend of population decline and threatened by various stressors, even though some of them are located within protected areas. Long-term monitoring data recorded a four-fold decline in nesting turtles in the Jamursba Medi (Mangubhai et al., 2012), and a decline of more than 50\% in the Derawan Island of Indonesia (MoF, 2014). In contrast to other measures of biodiversity, these areas had little spatial overlap with species richness. Thus, special measures are needed to protect these important sea turtles sites.

The criteria of species ranges, species occurrences, and restricted-range reef fishes were significantly correlated with the criteria of biogenic habitats. The diversity of species is expected to be influenced by the availability of biogenic habitats and habitat heterogeneity (Costello \& Chaudhary, 2017). In parallel, all of the ecological criteria were positively correlated with primary productivity, depth, and sea-surface temperature (SST). These abiotic factors have been frequently suggested as major variables that influence the distribution of marine biodiversity (Parravicini et al., 2013; Valentine \& Jablonski, 2015; Saeedi et al., 2016). Primary productivity was correlated with the criteria that correspond to species richness (i.e., species diversity, species of conservation concern and restricted-range reef fishes), as species abundance is likely affected by the availability of nutrients (Costello \& Chaudhary, 2017).

\subsection{Exploring multi-criteria analysis}

We investigated five different criteria to assess the intrinsic value of the biodiversity within the Coral Triangle. These criteria highlighted the value of critical habitat, species diversity, and of charismatic threatened, and endemic species. Advantages of using this approach to support the selection of sites of potential interest are its applicability to evaluate criteria in a transparent manner, providing alternative scenarios and allowing for incorporation of new data when it becomes available. It has been used over the past two decades and is commonly applied in land suitability analysis (Malczewski, 2006), environmental/urban planning (Geneletti et al., 2007) and biodiversity management (Bottero et al., 2013; Favretto et al., 2016; García Márquez et al., 2016).

Approximately $13 \%$ of the Coral Triangle was clustered into areas of high biodiversity importance. These areas were clustered along the southern part of the Philippines, in the north-eastern part of Sabah - Malaysia, in the center to the eastern part of Indonesia, in the eastern part of Papua New Guinea and adjacent to the Solomon Islands. These findings are broadly congruent with the Coral Triangle scientific boundary that was delineated based on reef-building coral biodiversity, as proposed by Green \& Mous (2008) and Veron et al. (2009).

The site-based analysis identified specific sites within areas of biodiversity importance. The most significant areas include four sites in Indonesia (i.e., northern tip of Sulawesi, Ambon Island, Kei Island, and Raja Ampat Archipelago of Papua) and three sites in the Philippines (i.e., the Verde Island Passage, the southern part of Negros Island, Cebu Island). The biodiversity values of those sites were supported by a full range of biogenic habitat and a high species diversity. All of these sites were predicted to be occupied by more than 4,000 marine species. In addition, three sites (i.e., northern tip of Sulawesi, Kei Island, and the southern part of Negros Island) were also identified as important habitat for three species of sea turtle. The Verde Island Passage was inhabited by a high number of species of conservation concern. Raja Ampat Archipelago was recognized as the host of more than 100 species of restricted-range reef fishes, which was the highest number in the Coral Triangle region (Fig. 5).

Studies of geographic conservation prioritization at a national level have suggested similar patterns to our analysis of areas of biodiversity importance. Huffard et al. (2012) used expert opinion to analyze patterns of species richness and endemism in Indonesian waters. Their Delphic analysis found that the ecoregion of Papua 
was rated as the top and the Banda Sea as the second ranked ecoregion for marine biodiversity conservation priority in Indonesia. The ecoregion of Papua (including Raja Ampat Archipelago) and the Banda Sea (including Ambon and Kei islands) hosts a high diversity of coral reef species and high habitat diversity, and contains significant areas for highly endemic and endangered species. In the Philippines, Ambal et al. (2012) identified 123 Marine Key Biodiversity Areas (mKBAs) using species ranges data of 641 globally threatened marine species. Of these, three were located in the Verde Island passage (i.e., Balayan Bay, Tinglao and Puerto Galera) and three in the southern part of Negros and Cebu Island (i.e., Bays Bay, Apo Island and Eastern part of Siquijor). Balayan Bay and Tinglao were identified as mKBAs with the largest number of indicator species (172 and 167 species, respectively), Bays Bay was inhabited by globally threatened mangroves, the eastern part of Siquijor was inhabited by threatened reef corals and molluscs, and Apo Island was inhabited by endangered reef corals and reef fishes.

This study has identified high conservation value areas with the best available data. However, as proposed by Asaad et al. (2016), three other ecological criteria are recommended to have a comprehensive assessment of the biodiversity conservation value of the region: unique and rare habitats, representativeness and ecological integrity. Comprehensive region-wide marine habitat maps using a standard habitat classification system are required to assess those three criteria. Unfortunately, a full list of habitats and associated maps are not currently available for the region. In addition, future work should also consider deep-sea biodiversity to identify suitable locations for deep-sea marine reserves.

Our analyses used a variety of ecological criteria to identify areas of biodiversity importance. The data were derived from different sources: satellite image interpretation (e.g., datasets of biogenic habitat), point occurrence records (e.g., datasets of conservation concern species and sea turtle nesting beaches), species distribution modelling (e.g., datasets of species richness), observation records and expert-drawn distribution patterns (e.g., restricted-range reef fishes), and telemetry data (e.g., sea turtle migratory routes). Remote sensing data and expert delineation maps provide species and habitat distribution maps over large areas including remote areas but may have a limited spatial accuracy. Conversely, point records provide a finer scale species occurrence but are prone to observer biases and are unlikely to fully cover species' ranges. Data from species distribution modelling such as AquaMaps that use species occurrence points in conjunction with environmental covariates (environmental niche models), are available for widespread and common species but may lack key habitat variables, such as seabed substratum. Systematically combining different biological and environmental datasets provides more balanced and representative information to delineate areas of importance for biodiversity conservation.

\section{Conclusion}

This study supports the application of marine biodiversity informatics to aid conservation prioritization. Here, we demonstrate an alternative approach to delineate areas of importance for biodiversity conservation. We used a range of ecological criteria, multiple sources of data and wide-ranging species taxonomic groups. Only a few regions in the world (e.g., Gulf of California (Sala et al., 2002), and the Great Barrier Reef of Australia (Fernandes et al., 2009)) have been as comprehensively assessed as our study. We found that approximately $13 \%$ of the Coral Triangle was clustered into areas of the high biodiversity importance (biodiversity hotspots). These areas were clustered along the southern part of the Philippines, the north-eastern part of Malaysian Sabah, central to eastern part of Indonesia, the eastern part of Papua New Guinea and the Solomon Islands. These included seven sites that were identified as the most important areas: three sites in the Philippines (i.e., the Verde Island Passage, the southern part of Negros Island and Cebu Island) and four sites in Indonesia (i.e., the northern tip of Sulawesi, Ambon Island, Kei Islands, and Raja Ampat Archipelago). Thus, we recommend that the biodiversity hotspot clusters and sites of biodiversity importance that we have identified here should be prioritized to be included in a network of protected reserve in the Coral Triangle.

Supplementary data to this article can be found online at https://figshare.com/s/0f47ffd0d1d068e39429, with DOI: $10.17608 / \mathrm{k} 6$.auckland.5035238.

\section{Acknowledgments}

IA is supported by New Zealand Aid Programme through New Zealand - ASEAN Scholarship. We would like to thank Dr Gerry Allen for providing endemic reef fishes distribution data, Christine Casal for the FishBase data, Cristina Garilao for the AquaMaps data, Ramlan Jamal, Ismail Ampulembang and Ahmad Mauliddin for assistance in reef fishes geo-database preparations and Chhaya Chaudhary for the species rarefaction technique. Finally, we would like to thank the Editor, Dr Amanda Bates, and three anonymous reviewers for their insightful comments on the manuscript. 


\section{References}

Allen, G.R. (2008). Conservation hotspots of biodiversity and endemism for Indo-Pacific coral reef fishes. Aquatic Conservation-Marine and Freshwater Ecosystems, 18(5), 541-556. DOI: 10.1002/Aqc.880.

Allen, G.R., \& Erdmann, M.V. (2009). Reef fishes of the Bird's Head Peninsula, West Papua, Indonesia. Check List: Journal of species lists and distribution. 5(3), 587-628.

Allen, G.R., \& Erdmann, M.V. (2013). Reef fishes of the East Indies. Mobile Application Software. Version 1.1 (Rev.10.2016). Retrieved 15/06/2016. https://geo.itunes.apple.com/us/app/reef-fishes-east-indiesvol./id705188551? $\mathrm{mt}=8$

Ambal, R., Duya, M., Cruz, M., Coroza, O., Vergara, S., De Silva, N., Molinyawe, N., \& Tabaranza, B. (2012). Key biodiversity areas in the Philippines: Priorities for conservation. Journal of Threatened Taxa, 4(8), 2788-2796.

Asaad, I., Lundquist, C.J., Erdmann, M.V., \& Costello, M.J. (2016). Ecological criteria to identify areas for biodiversity conservation. Biological Conservation. DOI: http://dx.doi.org/10.1016/j.biocon.2016.10.007

Asian Development Bank. (2014). Regional State of the Coral Triangle - Coral Triangle marine resources: Their status, economies, and management. Asian Development Bank. Mandaluyong City - The Philippines.

Ballantine, B. (2014). Fifty years on: Lessons from marine reserves in New Zealand and principles for a worldwide network Biological Conservation, 176, 297-307.

Basher, Z., Bowden, D.A., \& Costello, M.J. (2014). Global Marine Environment Datasets (GMED)- World Wide Web electronic publication. Version 1.0 (Rev.01.2014). Retrieved 15/01/2016 http://gmed.auckland.ac.nz

Beger, M., Jones, G.P., \& Munday, P.L. (2003). Conservation of coral reef biodiversity: a comparison of reserve selection procedures for corals and fishes. Biological Conservation, 111(1), 53-62. DOI: 10.1016/S0006-3207(02)00249-5.

Beger, M., McGowan, J., Treml, E.A., Green, A.L., White, A.T., Wolff, N.H., Klein, C.J., Mumby, P.J., \& Possingham, H.P. (2015). Integrating regional conservation priorities for multiple objectives into national policy. Nature Communications, 6:8208. DOI: 10.1038/ncomms9208.

Bisby, F.A., Ruggiero, M.A., Wilson, K.L., Cachuela-Palacio, M., Kimani, S.W., Roskov, Y.R., Soulier-Perkins, A., \& Van Hertum, J. (2005). Species 2000 \& ITIS Catalogue of Life: 2005 annual checklist CD-ROM. Species 2000.

Bottero, M., Comino, E., Duriavig, M., Ferretti, V., \& Pomarico, S. (2013). The application of a Multicriteria Spatial Decision Support System (MCSDSS) for the assessment of biodiversity conservation in the Province of Varese (Italy). Land Use Policy, 30(1), 730-738. doi: http://dx.doi.org/10.1016/j.landusepol.2012.05.015.

Boyle, T.P., Smillie, G.M., Anderson, J.C., \& Beeson, D.R. (1990). A sensitivity analysis of nine diversity and seven similarity indices. Research Journal of the Water Pollution Control Federation, 749-762.

Brooks, T. (2010). Conservation planning and priorities. In N.S. Sodhi \& P.R. Ehrlich (Eds.), Conservation biology for all (pp. 199-217). Oxford University Press. Oxford - UK.

Burke, L.M., Reytar, K., Spalding, M., \& Perry, A. (2012). Reefs at Risk Revisited in the Coral Triangle: World Resources Institute. Washington - USA.

Butchart, S.H., Clarke, M., Smith, R.J., Sykes, R.E., Scharlemann, J.P., Harfoot, M., Buchanan, G.M., Angulo, A., Balmford, A., \& Bertzky, B. (2015). Shortfalls and solutions for meeting national and global conservation area targets. Conservation Letters, $x x x$ 2015, 00(0), 1-9. DOI: 10.1111/conl.12158.

Clark, M.R., Rowden, A.A., Schlacher, T.A., Guinotte, J., Dunstan, P.K., Williams, A., O'Hara, T.D., Watling, L., Niklitschek, E., \& Tsuchida, S. (2014). Identifying Ecologically or Biologically Significant Areas (EBSA): A systematic method and its application to seamounts in the South Pacific Ocean. Ocean \& Coastal Management, 91, 65-79. DOI: 10.1016/j.ocecoaman.2014.01.016

Costello, M.J. (2014). Long live marine reserves: A review of experiences and benefits. Biological Conservation, 176, 289 296. DOI: http://dx.doi.org/10.1016/j.biocon.2014.04.023

Costello, M.J., \& Ballantine, B. (2015). Biodiversity conservation should focus on no-take Marine Reserves: 94\% of Marine Protected Areas allow fishing. Trends in Ecology \& Evolution, 30(9), 507-509.

Costello, M.J., \& Chaudhary, C. (2017). Marine biodiversity, biogeography, deep-sea gradients, and conservation. Current Biology, 27(11), R511-R527.

Costello, M. J. \& Emblow, C. (2005). A classification of inshore marine biotopes. In: Wilson J. G. (Eds.), The intertidal ecosystem: the value of Ireland's shores. Royal Irish Academy, Dublin - Ireland.

Costello, M.J., \& Vanden Berghe, E. (2006). 'Ocean biodiversity informatics': a new era in marine biology research and management. Marine Ecology Progress Series, 316, 203-214. Doi: 10.3354/Meps316203

Costello, M.J., Pohle G., \& Martin, A. (2004). Evaluating biodiversity in marine environmental assessments. Research and Development Monograph Series 2001. Canadian Environmental Assessment Agency. Ottawa - Canada.

Costello M.J., Vanhoorne B., \& Appeltans W. 2015. Progressing conservation of biodiversity through taxonomy, data publication and collaborative infrastructures. Conservation Biology 29 (4), 1094-1099.

Cros, A., Fatan, N.A., White, A., Teoh, S.J., Tan, S., Handayani, C., Huang, C., Peterson, N., Li, R.V., Siry, H.Y., Fitriana, R., Gove, J., Acoba, T., Knight, M., Acosta, R., Andrew, N., \& Beare, D. (2014a). The Coral Triangle Atlas: An Integrated Online Spatial Database System for Improving Coral Reef Management. Plos One, 9(6). doi: 10.1371/journal.pone.0096332.

CTI-CFF. (2009). The Regional Plan of Action of the Coral Triangle on Coral Reefs, Fisheries and Food Security (CTI$C F F)$ Initiative. Secretariat of CTI-CFF Initiative. Jakarta - Indonesia.

CTI-CFF. (2013). Coral Triangle Marine Protected Area System Framework and Action Plan. CTI-CFF, United States Agency for International Development Coral Triangle Support Partnership and US National Oceanic and Atmospheric Administration. Cebu City - The Philippines. 
Di Minin, E., Slotow, R., Hunter, L.T., Pouzols, F.M., Toivonen, T., Verburg, P.H., Leader-Williams, N., Petracca, L., \& Moilanen, A. (2016). Global priorities for national carnivore conservation under land use change. Scientific reports, 6.

Edgar, G.J., Stuart-Smith, R.D., Willis, T.J., Kininmonth, S., Baker, S.C., Banks, S., Barrett, N.S., Becerro, M.A., Bernard, A.T., \& Berkhout, J. (2014). Global conservation outcomes depend on marine protected areas with five key features. Nature, 506(7487), 216-220.

ESRI. (2016a). ArcGIS Desktop: Release 10.5. Environmental Systems Research Institute. ESRI. Redlands - CA.

ESRI. (2016b). ArcMap: Hot Spot Analysis (Getis-Ord Gi*). Retrieved 01/08/2016. http://desktop.arcgis.com/en/arcmap/10.3/tools/spatial-statistics-toolbox/hot-spot-analysis.htm

ESRI. (2016c). Ecological Marine Units. Retrieved 20/03/2017. http://www.esri.com/ecological-marine-units

Favretto, N., Stringer, L.C., Dougill, A.J., Dallimer, M., Perkins, J.S., Reed, M.S., Atlhopheng, J.R., \& Mulale, K. (2016). Multi-Criteria Decision Analysis to identify dryland ecosystem service trade-offs under different rangeland land uses. Ecosystem Services, 17, 142-151. DOI: http://dx.doi.org/10.1016/j.ecoser.2015.12.005.

Fernandes, L., Day, J., Kerrigan, B., Breen, D., De'ath, G., Mapstone, B., Coles, R., Done, T., Marsh, H., Poiner, I., Ward, T., Williams, D., \& Kenchington, R. (2009). A process to design a network of marine no-take areas: Lessons from the Great Barrier Reef. Ocean \& Coastal Management, 52(8), 439-447. DOI: https://doi.org/10.1016/j.ocecoaman.2009.06.004

Fisheries Act No 317 of Malaysia, (1985). Concerning on fisheries. Malaysia.

Fisheries Regulations of Malaysia (1999). Concerning on the control of endangered species of fish. Malaysia.

Foale, S., Adhuri, D., Alino, P., Allison, E.H., Andrew, N., Cohen, P., Evans, L., Fabinyi, M., Fidelman, P., Gregory, C., Stacey, N., Tanzer, J., \& Weeratunge, N. (2013). Food security and the Coral Triangle Initiative. Marine Policy, 38, 174-183. DOI: 10.1016/j.marpol.2012.05.033.

Food and Agricultural Organization. (2012). FISHSTAT Plus. Capture Production 1950-2010. Fisheries Information, Data and Statistics Unit. FAO - Fisheries Department. Roma - Italy.

Froese, R., \& Pauly, D. (2016). FishBase. World Wide Web electronic publication. Retrieved version (06/2016). www.fishbase.org,

García Márquez, J.R., Krueger, T., Páez, C.A., Ruiz-Agudelo, C.A., Bejarano, P., Muto, T., \& Arjona, F. (2016). Effectiveness of conservation areas for protecting biodiversity and ecosystem services: a multi-criteria approach. International Journal of Biodiversity Science, Ecosystem Services \& Management, 1-13. DOI: 10.1080/21513732.2016.1200672.

Geneletti, D., Bagli, S., Napolitano, P., \& Pistocchi, A. (2007). Spatial decision support for strategic environmental assessment of land use plans. A case study in southern Italy. Environmental Impact Assessment Review, 27(5), 408423.

Getis, A., \& Ord, J.K. (1992). The analysis of spatial association by use of distance statistics. Geographical analysis, 24(3), $189-206$.

Giri, C., Ochieng, E., Tieszen, L., Zhu, Z., Singh, A., Loveland, T., Masek, J., \& Duke, N. (2011a). Status and distribution of mangrove forests of the world using earth observation satellite data. Global Ecology and Biogeography, 20(1), $154-$ 159.

Giri, C., Ochieng, E., Tieszen, L., Zhu, Z., Singh, A., Loveland, T., Masek, J., \& Duke, N. (2011b). Global distribution of mangroves forests of the world using earth observation satellite data. In Supplement to: Giri et al. (2011a). UNEP World Conservation Monitoring Centre http://data.unep-wcmc.org/datasets/21. Cambridge - UK.

Green, A., \& Mous, P.J. (2008). Delineating the Coral Triangle, its ecoregions and functional seascapes TNC Coral Triangle Report. Coral Triangle Centre - The Nature Conservancy. Bali - Indonesia.

Green, A., Smith, S.E., Lipsett-Moore, G., Groves, C., Peterson, N., Sheppard, S., Lokani, P., Hamilton, R., Almany, J., \& Aitsi, J. (2009). Designing a resilient network of marine protected areas for Kimbe Bay, Papua New Guinea. Oryx, 43(04), 488-498.

Green, A.L., Fernandes, L., Almany, G., Abesamis, R., McLeod, E., Aliño, P.M., White, A.T., Salm, R., Tanzer, J., \& Pressey, R.L. (2014). Designing marine reserves for fisheries management, biodiversity conservation, and climate change adaptation. Coastal Management, 42(2), 143-159.

Greene, R., Devillers, R., Luther, J.E., \& Eddy, B.G. (2011). GIS-based multiple-criteria decision analysis. Geography Compass, 5(6), 412-432.

Hamilton, R.J., Potuku, T., \& Montambault, J.R. (2011). Community-based conservation results in the recovery of reef fish spawning aggregations in the Coral Triangle. Biological Conservation, 144(6), 1850-1858. DOI: http://dx.doi.org/10.1016/j.biocon.2011.03.024.

Hart, K.M., Zawada, D.G., Fujisaki, I., \& Lidz, B.H. (2013). Habitat use of breeding green turtles Chelonia mydas tagged in Dry Tortugas National Park: Making use of local and regional MPAs. Biological Conservation, 161, 142-154. DOI: http://dx.doi.org/10.1016/j.biocon.2013.03.019.

Heck, K.L., van Belle, G., \& Simberloff, D. (1975). Explicit calculation of the rarefaction diversity measurement and the determination of sufficient sample size. Ecology, 56(6), 1459-1461.

Hitipeuw, C., Dutton, P.H., Benson, S., Thebu, J., \& Bakarbessy, J. (2007). Population status and internesting movement of leatherback turtles, Dermochelys coriacea, nesting on the northwest coast of Papua, Indonesia. Chelonian Conservation and Biology, 6(1), 28-36.

Hoegh-Guldberg, O., Hoegh-Guldberg, H., Veron, J., Green, A., Gomez, E.D., Ambariyanto, A., \& Hansen, L. (2009). The Coral Triangle and climate change: ecosystems, people and societies at risk. WWF Australia. Brisbane - Australia.

Hoeksema, B.W. (2007). Delineation of the Indo-Malayan centre of maximum marine biodiversity: the Coral Triangle. In W. Renema (Ed.), Biogeography, time, and place: Distributions, barriers, and islands (pp. 117-178). Springer. The Netherlands 
Horton, T., Kroh, A., Bailly, N., Boury-Esnault, N., Brandão, S.N., Costello, M.J., Gofas, S., Hernandez, F., Mees, J., Paulay, G., Poore, G., Rosenberg, G., Stöhr, S., Decock, W., Dekeyzer, S., Vandepitte, L., Vanhoorne, B., Vranken, S., Adams, M.J., Adlard, R., Adriaens, P., Agatha, S., Ahn, K.J., Ahyong, S., Akkari, N., Alvarez, B., Anderson, G., Angel, M., Arango, C., Artois, T., Atkinson, S., Barber, A., Barbosa, J.P., Bartsch, I., Bellan-Santini, D., Berta, A., Bieler, R., Błażewicz, M., Bock, P., Böttger-Schnack, R., Bouchet, P., Boyko, C.B., Bray, R., Bruce, N.L., Cairns, S., Campinas Bezerra, T.N., Cárdenas, P., Carstens, E., Cedhagen, T., Chan, B.K., Chan, T.Y., Cheng, L., Churchill, M., Coleman, C.O., Collins, A.G., Cordeiro, R., Crandall, K.A., Cribb, T., Dahdouh-Guebas, F., Daly, M., Daneliya, M., Dauvin, J.C., Davie, P., De Grave, S., de Mazancourt, V., Decker, P., Defaye, D., d'Hondt, J.L., Dijkstra, H., Dohrmann, M., Dolan, J., Downey, R., Drapun, I., Eisendle-Flöckner, U., Eitel, M., Encarnação, S.C.d., Enghoff, H., Epler, J., Ewers-Saucedo, C., Faber, M., Feist, S., Finn, J., Fišer, C., Fonseca, G., Fordyce, E., Foster, W., Frank, J.H., Fransen, C., Furuya, H., Galea, H., Garcia-Alvarez, O., Gasca, R., Gaviria-Melo, S., Gerken, S., Gheerardyn, H., Gibson, D., Gil, J., Gittenberger, A., Glasby, C., Glover, A., Gordon, D., Grabowski, M., Gravili, C., GuerraGarcía, J.M., Guidetti, R., Guilini, K., Guiry, M.D., Hajdu, E., Hallermann, J., Hayward, B., Hendrycks, E., Herrera Bachiller, A., Ho, J.s., Høeg, J., Holovachov, O., Hooper, J., Hughes, L., Hummon, W., Hyzny, M., Iniesta, L.F.M., Iseto, T., Ivanenko, S., Iwataki, M., Jarms, G., Jaume, D., Jazdzewski, K., Kaminski, M., Karanovic, I., Kim, Y.H., King, R., Kirk, P.M., Kociolek, J.P., Kolb, J., Kotov, A., Krapp-Schickel, T., Kremenetskaia, A., Kristensen, R., Kullander, S., La Perna, R., Lambert, G., Lazarus, D., Le Coze, F., LeCroy, S., Leduc, D., Lefkowitz, E.J., Lemaitre, R., Lörz, A.N., Lowry, J., Macpherson, E., Madin, L., Mah, C., Mamos, T., Manconi, R., Mapstone, G., Marek, P.E., Marshall, B., Marshall, D.J., McInnes, S., Meidla, T., Meland, K., Merrin, K., Messing, C., Miljutin, D., Mills, C., Mokievsky, V., Molodtsova, T., Monniot, F., Mooi, R., Morandini, A.C., Moreira da Rocha, R., Moretzsohn, F., Mortelmans, J., Mortimer, J., Musco, L., Neubauer, T.A., Neuhaus, B., Ng, P., Nguyen, A.D., Nielsen, C., Nishikawa, T., Norenburg, J., O'Hara, T., Okahashi, H., Opresko, D., Osawa, M., Ota, Y., Patterson, D., Paxton, H., Perrier, V., Perrin, W., Petrescu, I., Picton, B., Pilger, J.F., Pisera, A., Polhemus, D., Pugh, P., Reimer, J.D., Reip, H., Reuscher, M., Rius, M., Rützler, K., Rzhavsky, A., Saiz-Salinas, J., Santos, S., Sartori, A.F., Satoh, A., Schatz, H., Schierwater, B., Schmidt-Rhaesa, A., Schneider, S., Schönberg, C., Schuchert, P., Senna, A.R., Serejo, C., Shamsi, S., Sharma, J., Shenkar, N., Short, M., Sicinski, J., Siegel, V., Sierwald, P., Simmons, E., Sinniger, F., Sivell, D., Sket, B., Smit, H., Smol, N., Souza-Filho, J.F., Spelda, J., Stampar, S.N., Sterrer, W., Stienen, E., Stoev, P., Strand, M., Suárez-Morales, E., Summers, M., Suttle, C., Swalla, B.J., Taiti, S., Tandberg, A.H., Tang, D., Tasker, M., Taylor, J., Tchesunov, A., ten Hove, H., ter Poorten, J.J., Thomas, J., Thuesen, E.V., Thurston, M., Thuy, B., Timi, J.T., Timm, T., Todaro, A., Turon, X., Tyler, S., Uetz, P., Utevsky, S., Vacelet, J., Vader, W., Väinölä, R., van der Meij, S.E., van Soest, R., Van Syoc, R., Venekey, V., Vonk, R., Vos, C., Walker-Smith, G., Walter, T.C., Watling, L., Wesener, T., Whipps, C., White, K., Williams, G., Wilson, R., Wyatt, N., Wylezich, C., Yasuhara, M., Zanol, J., \& Zeidler, W. (2016). World Register of Marine Species (WoRMS). Retrieved 10/01/2016, from WoRMS Editorial Board http://www.marinespecies.org.

Huffard, C.L., Erdmann, M.V., \& Gunawan, T.R.P. (2012). Geographic Priorities for Marine Biodiversity Conservation in Indonesia. Ministry of Marine Affairs and Fisheries and Marine Protected Areas Governance Program. Jakarta Indonesia.

Hurlbert, S.H. (1971). The nonconcept of species diversity: a critique and alternative parameters. Ecology, 52(4), 577-586.

IMaRS-USF., \& IRD. (2005). Millennium Coral Reef Mapping Project. Validated maps. UNEP World Conservation Monitoring Centre. Cambridge - UK.

IUCN. (2015). The IUCN Red List of Threatened Species. Version 2015.8. Retrieved 01/08/2015 http://www.iucnredlist.org. IUCN \& UNEP-WCMC. (2016). The World Database on Protected Areas (WDPA). Retrieved 01/08/2016, from UNEP World Conservation Monitoring Centre. www.protectedplanet.net. Cambridge - UK.

Jenkins, C.N., \& Van Houtan, K.S. (2016). Global and regional priorities for marine biodiversity protection. Biological Conservation. DOI: http://dx.doi.org/10.1016/j.biocon.2016.10.005.

Jetz, W., Sekercioglu, C.H., \& Watson, J.E. (2008). Ecological correlates and conservation implications of overestimating species geographic ranges. Conservation Biology, 22(1), 110-119.

JNCC. (2015). The Marine Habitat Classification for Britain and Ireland Version 15.03 [Online]. Retrieved 10/08/2016. http:// jncc.defra.gov.uk/MarineHabitatClassification

Juffe-Bignoli, D., Burgess, N., Bingham, H., Belle, E., de Lima, M., Deguignet, M., Bertzky, B., Milam, A., MartinezLopez, J., \& Lewis, E. (2014). Protected Planet Report 2014: UNEP-WCMC. Cambridge - UK.

Kaschner, K., Rius-Barile, J., Kesner-Reyes, K., Garilao, C., Kullander, S.O., Rees, T., \& Froese, R. (2016). AquaMaps: Predicted range maps for aquatic species. Worldwide web electronic publication, www.aquamaps.org. Version 08/2016

Klein, C.J., Brown, C.J., Halpern, B.S., Segan, D.B., McGowan, J., Beger, M., \& Watson, J.E. (2015). Shortfalls in the global protected area network at representing marine biodiversity. Scientific Reports, 5:17539. DOI: $10.1038 /$ srep 17539.

Lack, M., \& Sant, G. (2011). The future of sharks: a review of action and inaction (pp. 44). TRAFFIC International and the Pew Environment Group. Cambridge - UK.

Lack, M., \& Sant, G. (2012). An overview of shark utilisation in the Coral Triangle region. TRAFFIC \& WWF. Cambridge UK.

Langhammer, P.F., Bakar, M.I., Bennun, L.A., Brooks, T.M., Rob P. Clay, Darwall, W., Silva, N.D., Edgar, G.J., Eken, G., Fishpool, L.D.C., Fonseca, G.A.B.d., Matthew N. Foster, Knox, D.H., Matiku, P., Radford, E.A., Rodrigues, A.S.L., Salaman, P., Sechrest, W., \& Tordoff, A.W. (2007). Identification and gap analysis of key biodiversity areas: targets for comprehensive protected area systems: IUCN. Gland - Switzerland. 
Laffoley, D., White, A.T., Kilarski, S., Gleason, M., Smith, S., Llewellyn, G., Day, J., Hillary, A., Wedell, V., \& Pee, D. (2008). Establishing Resilient Marine Protected Area Networks-Making it Happen. IUCN-WCPA, National Oceanic and Atmospheric Administration and The Nature Conservancy. Washington, DC.

Leathwick, J.R., Rowden, A., Nodder, S., Gorman, R., Bardsley, S., Pinkerton, M., Baird, S., Hadfield, M., Currie, K., \& Goh, A. (2012). A benthic-optimised marine environment classification (BOMEC) for New Zealand waters New Zealand Aquatic Environment and Biodiversity Report 88 (pp. 54). Ministry of Fisheries of New Zealand. Wellington-New Zealand.

Leleu, K., Remy-Zephir, B., Grace, R., \& Costello, M.J. (2012). Mapping habitats in a marine reserve showed how a 30-year trophic cascade altered ecosystem structure. Biological Conservation, 155, 193-201. Doi: http://dx.doi.org/10.1016/j.biocon.2012.05.009.

Malczewski, J. (2006). GIS-based multicriteria decision analysis: A survey of the literature. International Journal of Geographical Information Science, 20(7), 703-726.

Mangubhai, S., Erdmann, M.V., Wilson, J.R., Huffard, C.L., Ballamu, F., Hidayat, N.I., Hitipeuw, C., Lazuardi, M.E., Muhajir, Pada, D., Purba, G., Rotinsulu, C., Rumetna, L., Sumolang, K., \& Wen, W. (2012). Papuan Bird's Head Seascape: Emerging threats and challenges in the global center of marine biodiversity. Marine Pollution Bulletin, 64(11), 2279-2295. DOI: http://dx.doi.org/10.1016/j.marpolbul.2012.07.024.

McLeod, E., Green, A., Game, E., Anthony, K., Cinner, J., Heron, S.F., Kleypas, J., Lovelock, C.E., Pandolfi, J.M., Pressey, R.L., Salm, R., Schill, S., \& Woodroffe, C. (2012). Integrating climate and ocean change vulnerability into conservation planning. Coastal Management, 40(6), 651-672. DOI: 10.1080/08920753.2012.728123.

Mellin, C., Aaron MacNeil, M., Cheal, A.J., Emslie, M.J., \& Julian Caley, M. (2016). Marine protected areas increase resilience among coral reef communities. Ecology Letters, DOI: 10.1111/ele.12598.

MoF. (2014). Strategy and action plan for the conservation of sea turtles in Indonesia 2014 - 2023. Ministry of Forestry. Jakarta-Indonesia.

MoF-MoMAF. (2010). Ecological representation gap analysis for conservation areas in Indonesia (pp. 29). Ministry of Forestry and Ministry of Marine Affairs and Fisheries. Jakarta-Indonesia.

MoMAF. (2016). Database of Marine Protected Areas in Indonesia. Ministry of Marine Affairs and Fisheries. Jakarta Indonesia.

MWWP. (2014). Philippine aquatic wildlife rescue and response manual series: Marine turtles. (pp. 86). Marine Wild Fauna Watch of the Philippines (MWWP) Inc. Manila - The Philippines.

OBIS. (2015). Data from the Ocean Biogeographic Information System. Intergovernmental Oceanographic Commission of UNESCO. Retrieved 02/05/2015. http://www.iobis.org.

Ord, J.K., \& Getis, A. (1995). Local spatial autocorrelation statistics: distributional issues and an application. Geographical analysis, 27(4), 286-306.

Parravicini, V., Kulbicki, M., Bellwood, D., Friedlander, A., Arias-Gonzalez, J., Chabanet, P., Floeter, S., Myers, R., Vigliola, L., \& D'Agata, S. (2013). Global patterns and predictors of tropical reef fish species richness. Ecography, 36(12), 1254-1262.

Péron, C., Grémillet, D., Prudor, A., Pettex, E., Saraux, C., Soriano-Redondo, A., Authier, M., \& Fort, J. (2013). Importance of coastal Marine Protected Areas for the conservation of pelagic seabirds: The case of Vulnerable yelkouan shearwaters in the Mediterranean Sea. Biological Conservation, 168, 210-221.

Polhemus, D. (2007). Tectonic geology of Papua. The ecology of Papua. The ecology of Indonesia Series VI. (pp. 137-164). Periplus Editions. Hongkong.

Polidoro, B.A., Carpenter, K.E., Collins, L., Duke, N.C., Ellison, A.M., Ellison, J.C., Farnsworth, E.J., Fernando, E.S., Kathiresan, K., Koedam, N.E., Livingstone, S.R., Miyagi, T., Moore, G.E., Vien, N.N., Ong, J.E., Primavera, J.H., Salmo, S.G., Sanciangco, J.C., Sukardjo, S., Wang, Y.M., \& Yong, J.W.H. (2010). The loss of species: Mangrove extinction risk and geographic areas of global concern. Plos One, 5(4). DOI: 10.1371/journal.pone.0010095

Polidoro, B.A., Livingstone, S.R., Carpenter, K.E., Hutchinson, B., Mast, R.B., Pilcher, N.J., de Mitcheson, Y.S., \& Valenti, S.V. (2009). Status of the world's marine species: In JC Vié, C Hilton-Taylor, \& SN Stuart (Ed.), Wildlife in a changing world - An analysis of the 2008 IUCN Red List of Threatened Species (pp. 55). IUCN. Gland-Switzerland.

R Core Team. (2016). R: A language and environment for statistical computing: R Foundation for Statistical Computing. http://www.R-project.org/. Vienna-Austria.

Rees, T. (2003). C-squares, a new spatial indexing system and its applicability to the description of oceanographic datasets. Oceanography, 16(1), 11-19.

Reiss, H., \& Kröncke, I. (2005). Seasonal variability of benthic indices: An approach to test the applicability of different indices for ecosystem quality assessment. Marine Pollution Bulletin, 50(12), 1490-1499. DOI: http://dx.doi.org/10.1016/j.marpolbul.2005.06.017

Republic Act No. 9147 of the Phillipines (2001). Concerning on the conservation and protection of wildlife resources and their habitats. The Philippines.

Ricketts, T.H., Dinerstein, E., Boucher, T., Brooks, T.M., Butchart, S.H., Hoffmann, M., Lamoreux, J.F., Morrison, J., Parr, M., \& Pilgrim, J.D. (2005). Pinpointing and preventing imminent extinctions. Proceedings of the National Academy of Sciences of the United States of America, 102(51), 18497-18501.

Roberts, J.M., Wheeler, A.J., \& Freiwald, A. (2006). Reefs of the deep: the biology and geology of cold-water coral ecosystems. Science, 312(5773), 543-547.

Roff, J., \& Zacharias, M. (2011). Marine Conservation Ecology. Earthscan. London - UK.

Russ, G.R., \& Alcala, A.C. (2010). Decadal-scale rebuilding of predator biomass in Philippine marine reserves. Oecologia, 163(4), 1103-1106.

Saeedi, H., Dennis, T.E., \& Costello, M.J. (2016). Bimodal latitudinal species richness and high endemicity of razor clams (Mollusca). Journal of Biogeography. DOI: 10.1111/jbi.12903. 
Sanders, H.L. (1968). Marine benthic diversity: a comparative study. American Naturalist, 243-282.

Sala, E., Aburto-Oropeza, O., Paredes, G., Parra, I., Barrera, J.C., \& Dayton, P.K. (2002). A general model for designing networks of marine reserves. Science, 298(5600), 1991-1993.

Selig, E.R., \& Bruno, J.F. (2010). A global analysis of the effectiveness of marine protected areas in preventing coral loss. PLoS One, 5(2), e9278.

Smith, A.N., Anderson, M.J., Millar, R.B., \& Willis, T.J. (2014). Effects of marine reserves in the context of spatial and temporal variation: an analysis using Bayesian zero-inflated mixed models. Marine Ecology Progress Series, 499, 203-216.

Stevens, J.D., Walker, T.I., Cook, S.F., \& Fordham, S.V. (2005). Threats faced by chondrichthyan fish. In S. Fowler, RD Cavanagh, M. Camhi, GH Burgess, GM Cailliet, SV Fordham, CA Simpfendorfer and JA Musick (Ed.), Sharks, Rays and Chimaeras: The Status of the Chondrichthyan Fishes. Status Survey (pp. 48-57). IUCN/SSC Shark Specialist Group. Gland - Switzerland and Cambridge - UK.

UNEP-WCMC (2015). The Checklist of CITES Species Website. http://checklist.cites.org. Retrieved 01/02/2016. CITES Secretariat, Geneva - Switzerland. Compiled by UNEP-WCMC. Cambridge - UK.

UNEP-WCMC, \& Short FT. (2005). Global distribution of seagrasses (version 2). UNEP World Conservation Monitoring Centre. Http:// data.unepwcmc.org/datasets/10 (polygons) and data.unep-wcmc.org/datasets/9 (points). Cambridge UK.

UNEP-WCMC, WorldFish Centre, WRI, \& TNC. (2010). Global distribution of warmwater coral reefs. UNEP-World Conservation Monitoring Centre http://data.unep-wcmc.org/datasets/13. Cambridge - UK.

Unsworth, R.K.F., \& Cullen, L.C. (2010). Recognising the necessity for Indo-Pacific seagrass conservation. Conservation Letters, 3(2), 63-73. DOI: 10.1111/j.1755-263X.2010.00101.x.

Valentine, J.W., \& Jablonski, D. (2015). A twofold role for global energy gradients in marine biodiversity trends. Journal of Biogeography, 42(6), 997-1005. DOI: 10.1111/jbi.12515

Venter, O., Fuller, R.A., Segan, D.B., Carwardine, J., Brooks, T., Butchart, S.H., Di Marco, M., Iwamura, T., Joseph, L., \& O'Grady, D. (2014). Targeting global protected area expansion for imperiled biodiversity. PLoS biology, 12(6), e1001891.

Veron, J., Devantier, L.M., Turak, E., Green, A.L., Kininmonth, S., Stafford-Smith, M., \& Peterson, N. (2009). Delineating the Coral Triangle. Galaxea, Journal of Coral Reef Studies, 11(2), 91-100.

VLIZ. (2014). Maritime Boundaries Geodatabase. Retrieved 22/03/2016 http://www.marineregions.org. Version 8.

Waheed, Z., \& Hoeksema, B.W. (2013). A tale of two winds: species richness patterns of reef corals around the Semporna peninsula, Malaysia. Marine Biodiversity, 43(1), 37-51.

Walton, A., White, A.T., Tighe, S., Alino, P.M., Laroya, L., Dermawan, A., Kasasiah, A., Hamid, S.A., Vave-Karamui, A., Genia, V., Martins, L.D., \& Green, A.L. (2014). Establishing a functional region-wide Coral Triangle marine protected area system. Coastal Management, 42(2), 107-127. DOI: 10.1080/08920753.2014.877765

Watson, J.E.M., Dudley, N., Segan, D.B., \& Hockings, M. (2014). The performance and potential of protected areas. Nature, 515(7525), 67-73. DOI: 10.1038/nature13947.

Weatherdon, L.V., Fletcher, R., Jones, M.C., Kaschner, K., Sullivan, E., Tittensor, D.P., Mcowen, C., Geffert, J.L., Van Bochove, J.W., Thomas, H., Blyth, S., Ravillious, C., Tolley, M., Stanwell-Smith, D., Fletcher, S., \& Martin, C.S. (2015). Manual of marine and coastal datasets of biodiversity importance. December 2015 edition. UNEP World Conservation Monitoring Centre. Cambridge - UK.

Weeks, R., Alino, P.M., Atkinson, S., Beldia, P., Binson, A., Campos, W.L., Djohani, R., Green, A.L., Hamilton, R., Horigue, V., Jumin, R., Kalim, K., Kasasiah, A., Kereseka, J., Klein, C., Laroya, L., Magupin, S., Masike, B., Mohan, C., Pinto, R.M.D., Vave-Karamui, A., Villanoy, C., Welly, M., \& White, A.T. (2014). Developing marine protected area networks in the Coral Triangle: Good practices for expanding the Coral Triangle marine protected area system. Coastal Management, 42(2), 183-205. DOI: 10.1080/08920753.2014.877768.

White, A.T., Aliño, P.M., Cros, A., Fatan, N.A., Green, A.L., Teoh, S.J., Laroya, L., Peterson, N., Tan, S., \& Tighe, S. (2014). Marine protected areas in the Coral Triangle: Progress, issues, and options. Coastal Management, 42(2), 87106.

White, W., \& Kyne, P. (2010). The status of chondrichthyan conservation in the Indo-Australasian region. Journal of fish biology, 76(9), 2090-2117.

Williams, I.D., Walsh, W.J., Claisse, J.T., Tissot, B.N., \& Stamoulis, K.A. (2009). Impacts of a Hawaiian marine protected area network on the abundance and fishery sustainability of the yellow tang, Zebrasoma flavescens. Biological Conservation, 142(5), 1066-1073. DOI: http://dx.doi.org/10.1016/i.biocon.2008.12.029.

Yeager, L.A., Marchand, P., Gill, D.A., Baum, J.K., \& McPherson, J.M. (2017). MSEC: Queryable global layers of environmental and anthropogenic variables for marine ecosystem studies. Ecology. DOI: 10.1002/ecy.1884 


\section{Supplementary}

\section{Data}

Table D1. Distribution of biogenic habitats, species ranges, species occurrence, species of conservation concern, restricted-range reef fishes and sea turtles included in the analyses, their hotspots and site priority attributes in 0.5 degree cells.

Table D2. The attribute of environmental variables included in the analyses in $0.5^{\circ}$ grid cells.

Map 1. Regional-based areas of biodiversity importance.

Map 2. Site-based areas of biodiversity importance.

\section{Supplementary Materials}

Figure S1. Number of records against number of species recorded at $0.5^{\circ}$ grid cells: (a) all taxonomic groups in OBIS, (b) species of conservation concern.

Figure S2. Distribution of 373 restricted-range reef fishes in $0.5^{\circ}$ grid cells. Species with the largest distribution include: A (Ostorhinchus neotes), B (Trimma rubromaculatum), C (Trimma haimassum), $\mathrm{D}$ (Halichoeres binotopsis) and the smallest distribution: E (Pseudanthias mica).

Figure S3. Distribution of nesting sites and migratory route of six sea turtle in $0.5^{\circ}$ grid cells. Sea turtles include CC (Caretta caretta); CM (Chelonia mydas); DC (Dermochelys coriacea); EI (Eretmochelys imbricata); LO (Lepidochelys olivacea); and ND (Natator depressus).

Figure S4. Venn diagram of spatial overlap among five criteria, indicating the proportion of the highest biodiversity cells shared by all five criteria and the proportion of highest biodiversity cells unique to each criterion.

Table S1. List of species and the occurrence points extracted from OBIS on 02/05/2015.

Table S2. List of species of conservation concern in the CT based on IUCN Red List, the CITES and national regulations of Indonesia, Malaysia and the Philippines.

Table S3. List of restricted-range reef fishes in the CT.

Table S4. Occurrence records of sea turtles in the CT extracted from OBIS and MoMAF datasets.

Table S5. Descriptive statistics of 16 environmental variable extracted from GMED.

Table S6. List of datasets used in this study extracted from OBIS on 02/05/2015. 


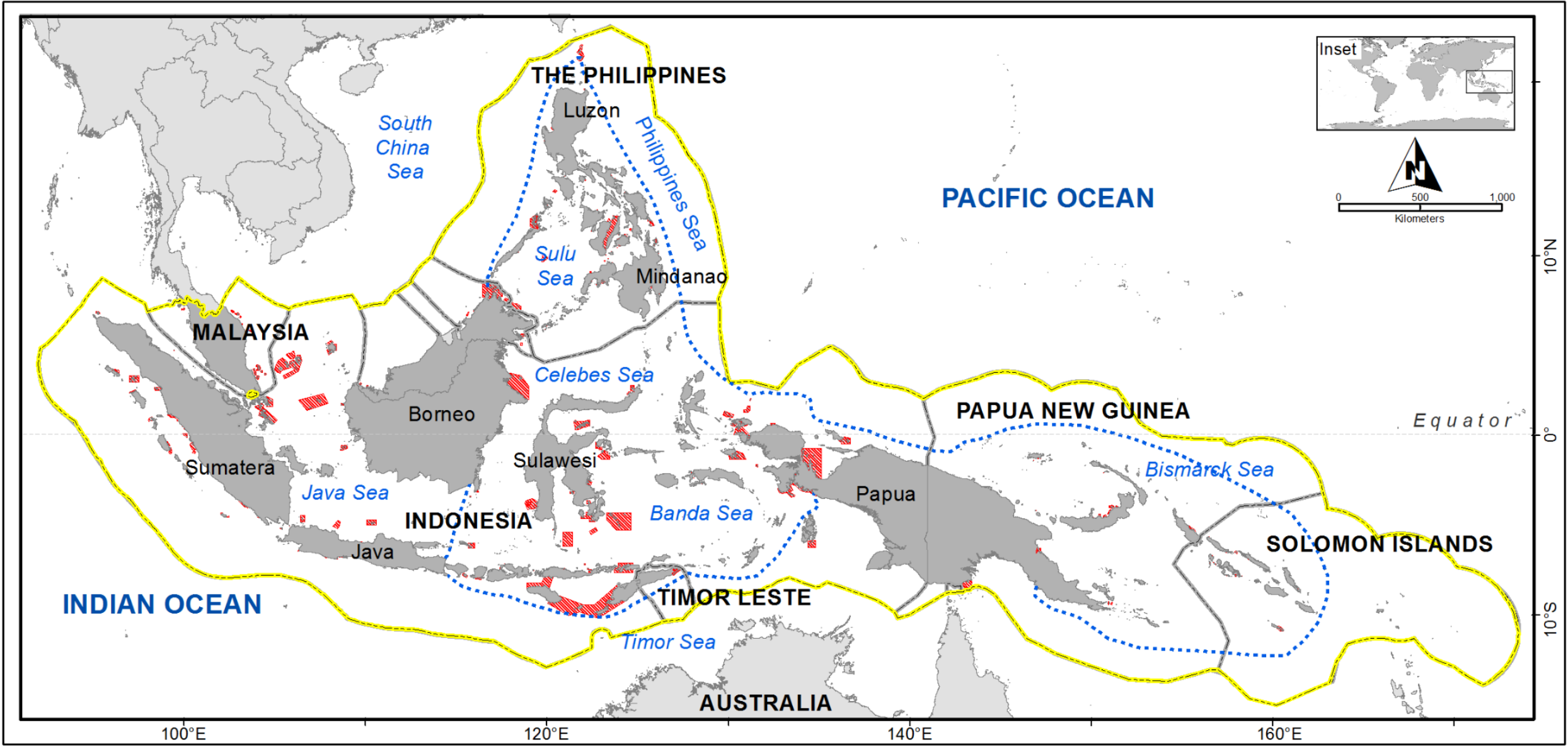

Figure 1. Map of the Coral Triangle. The CT countries EEZ outer (yellow-dashed line) (representing the Coral Triangle Initiatives implementation area) and internal boundaries (grey-dashed line), and the CT scientific boundary (proposed by Veron et al., 2009) (blue dashed line) are indicated. Nearly 2,000 MPAs occur in the area (red). 

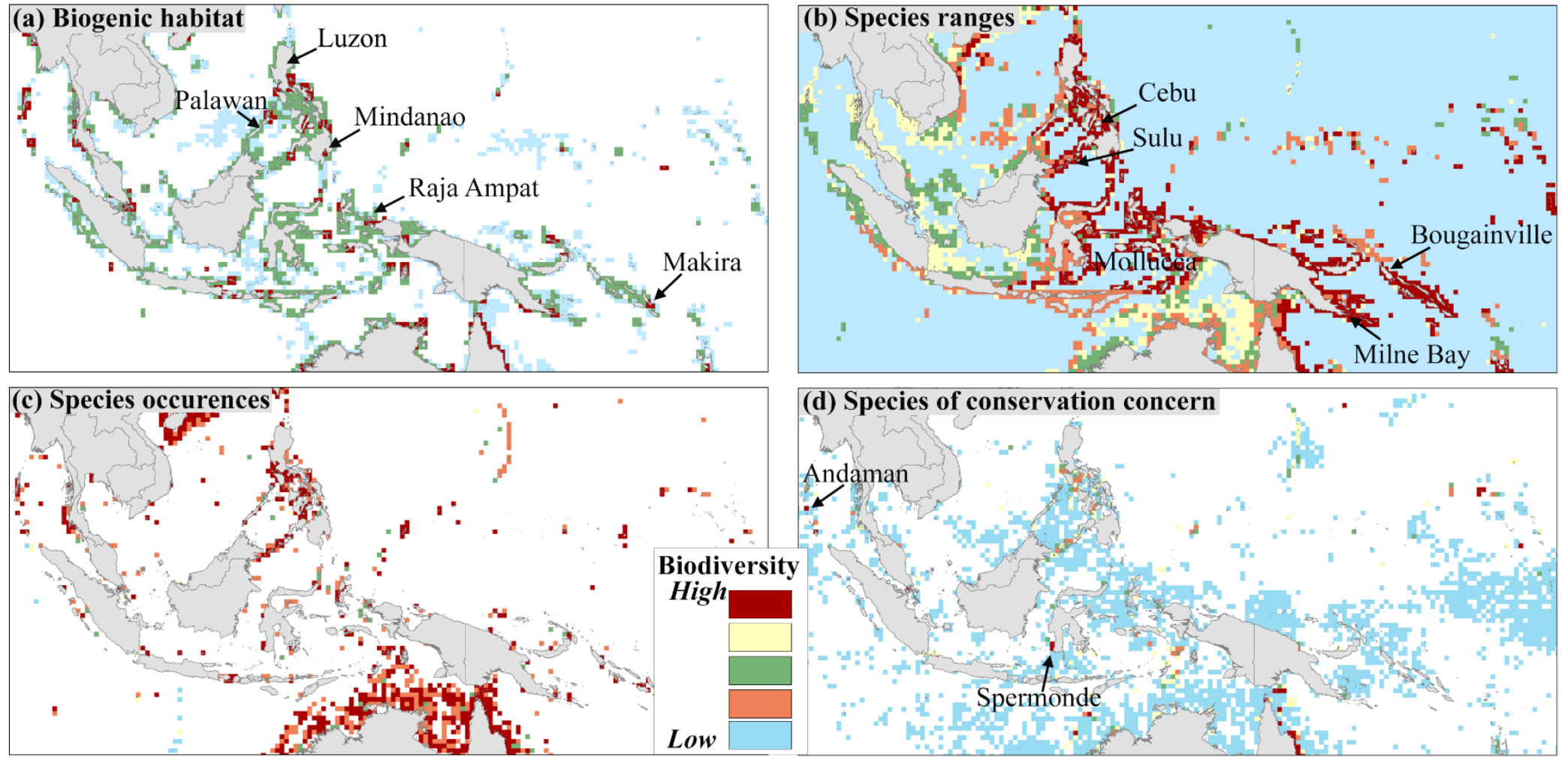

(e) Restricted-range reef fishes
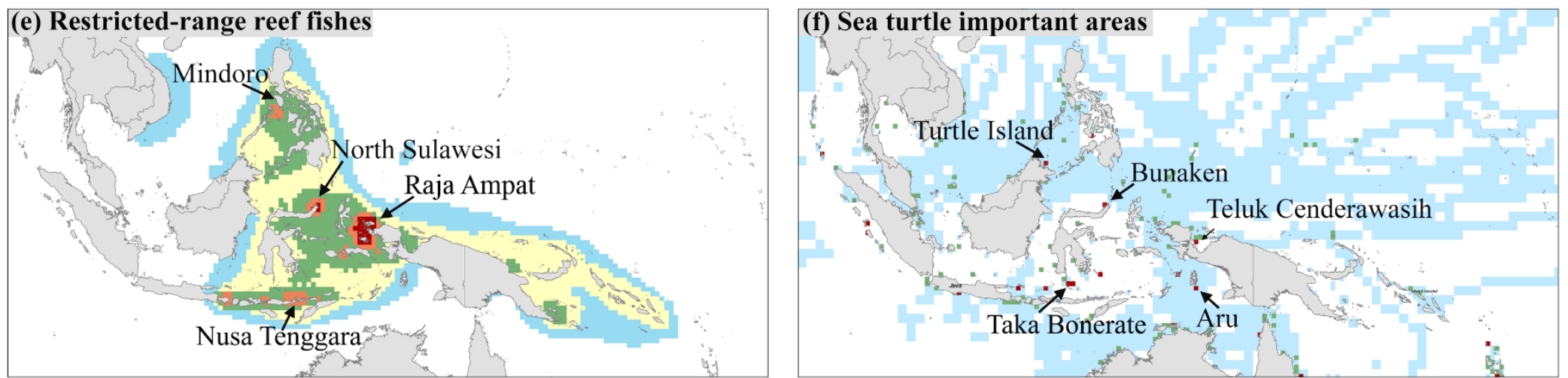

Figure 2. Areas of biodiversity importance based on each criterion in $0.5^{\circ}$ cells: (a) Coverage of coral reefs, mangroves and seagrasses, (b) Species richness based on the overlapped ranges of 10,672 species, (c) Species richness (occurrences) based on $\mathrm{ES}_{50}$ of 19,251 species, (d) Richness of species of conservation concern based on $\mathrm{ES}_{35}$ of 834 species, (e) Restricted-range species based on the distribution of $373 \mathrm{CT}$ endemic reef fishes, (e) Areas important for sea turtles based on the distribution of six sea turtle species. White cells $=$ No data. 

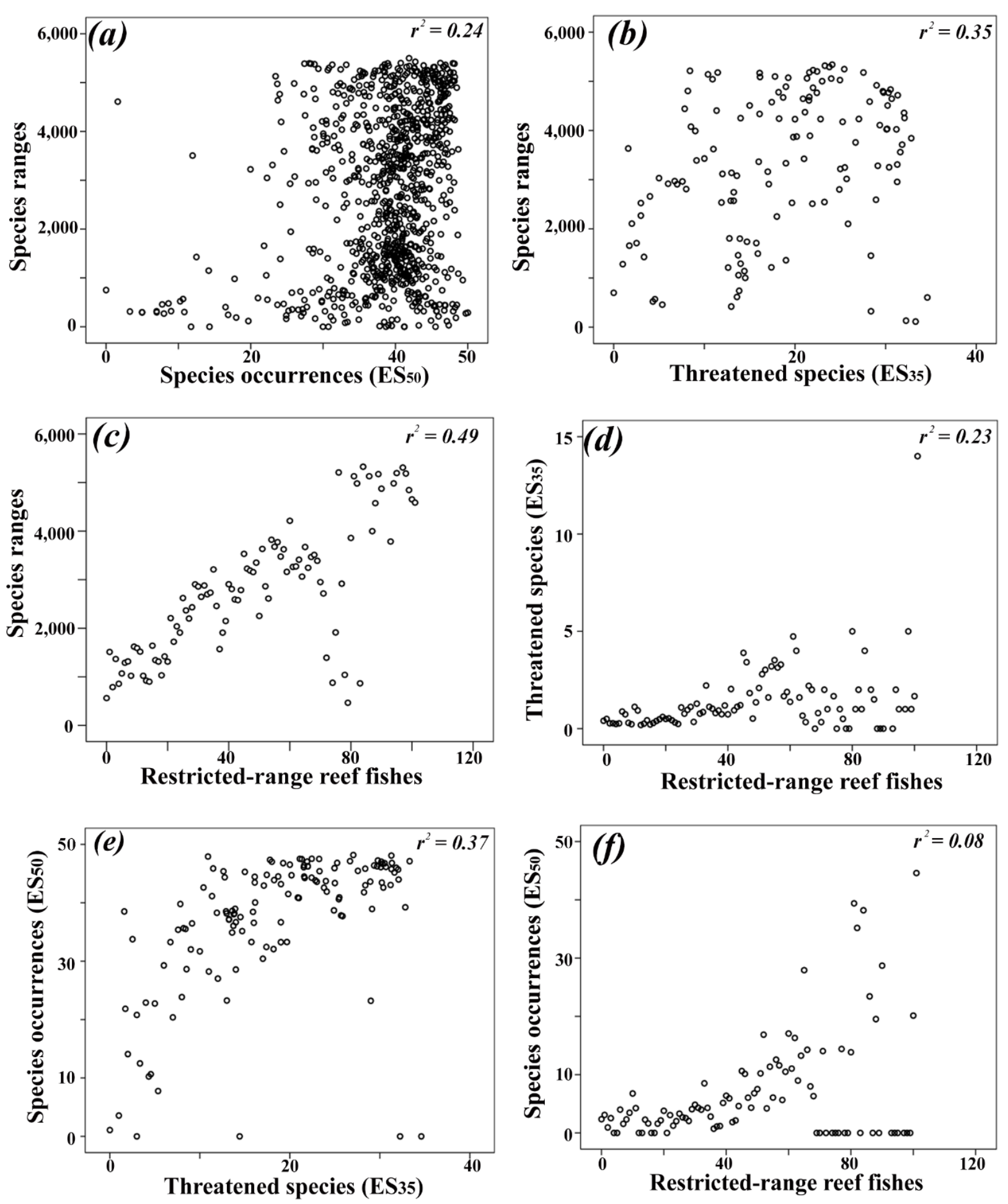

Figure 3. Correlation between the ecological criteria in $0.5^{\circ}$ grid cells: (a) Species richness (ranges) (AquaMaps) and $\mathrm{ES}_{50}$ of species richness (OBIS); (b) Species ranges (AquaMaps) and $\mathrm{ES}_{35}$ of species of conservation concern; (c) Species ranges and number of restricted-range reef fishes; (d) $\mathrm{ES}_{35}$ of species of conservation concern and number of restricted-range reef fishes; (e) $\mathrm{ES}_{50}$ of species richness (OBIS) and $\mathrm{ES}_{35}$ of species of conservation concern; (f) $\mathrm{ES}_{50}$ of species richness (OBIS) and number of restricted-range reef fishes. Number of cells $(n)=13,360$ cells. 


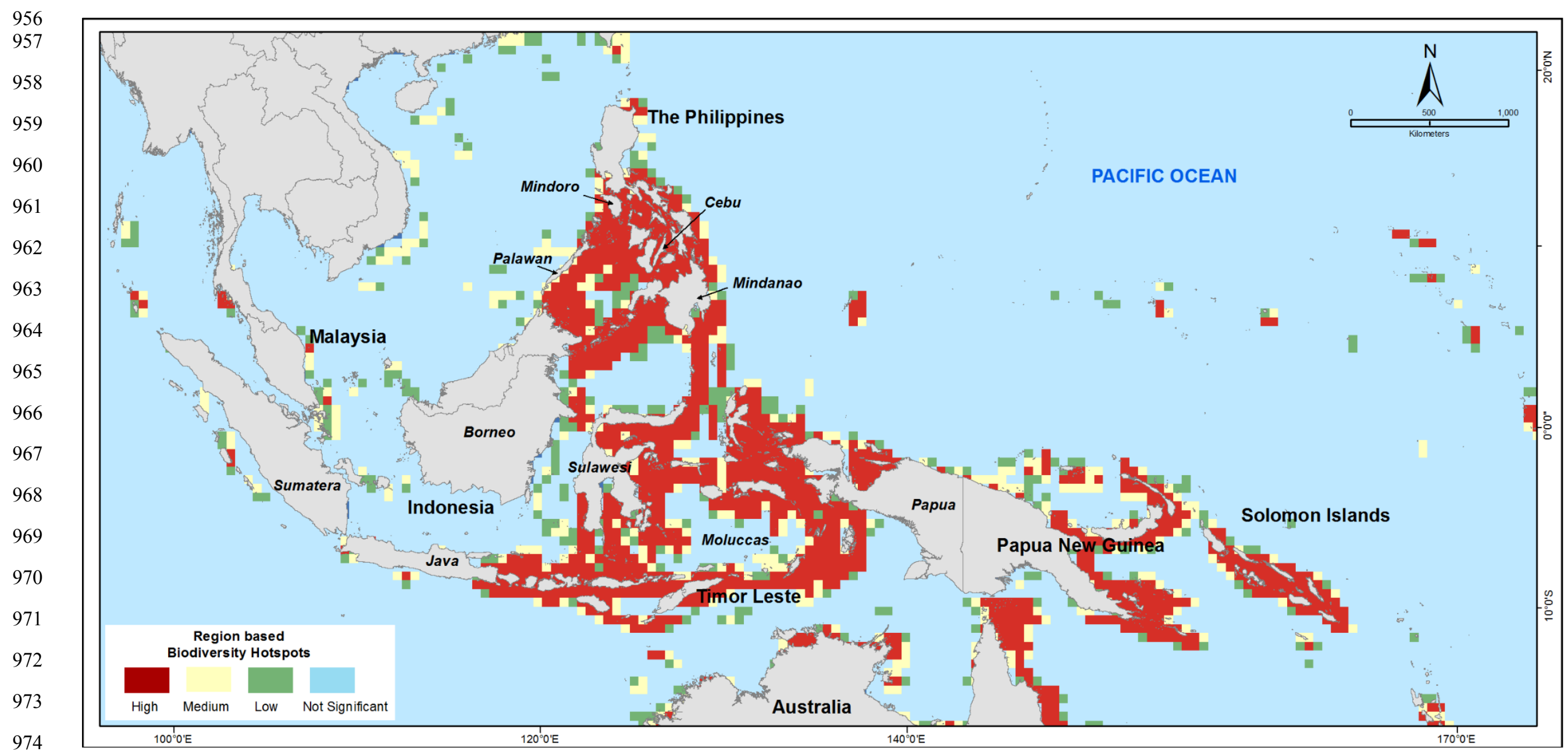

Figure 4. Map of clusters of cells of biodiversity importance in the Coral Triangle. Analyzed using hotspots analysis tools, the map shows spatially contiguous cells that have high biodiversity score. The analysis clustered the biodiversity score of adjacent cells into three hotspots classes: high (red), medium (yellow), low (green), and one non-significant cluster (light blue). 


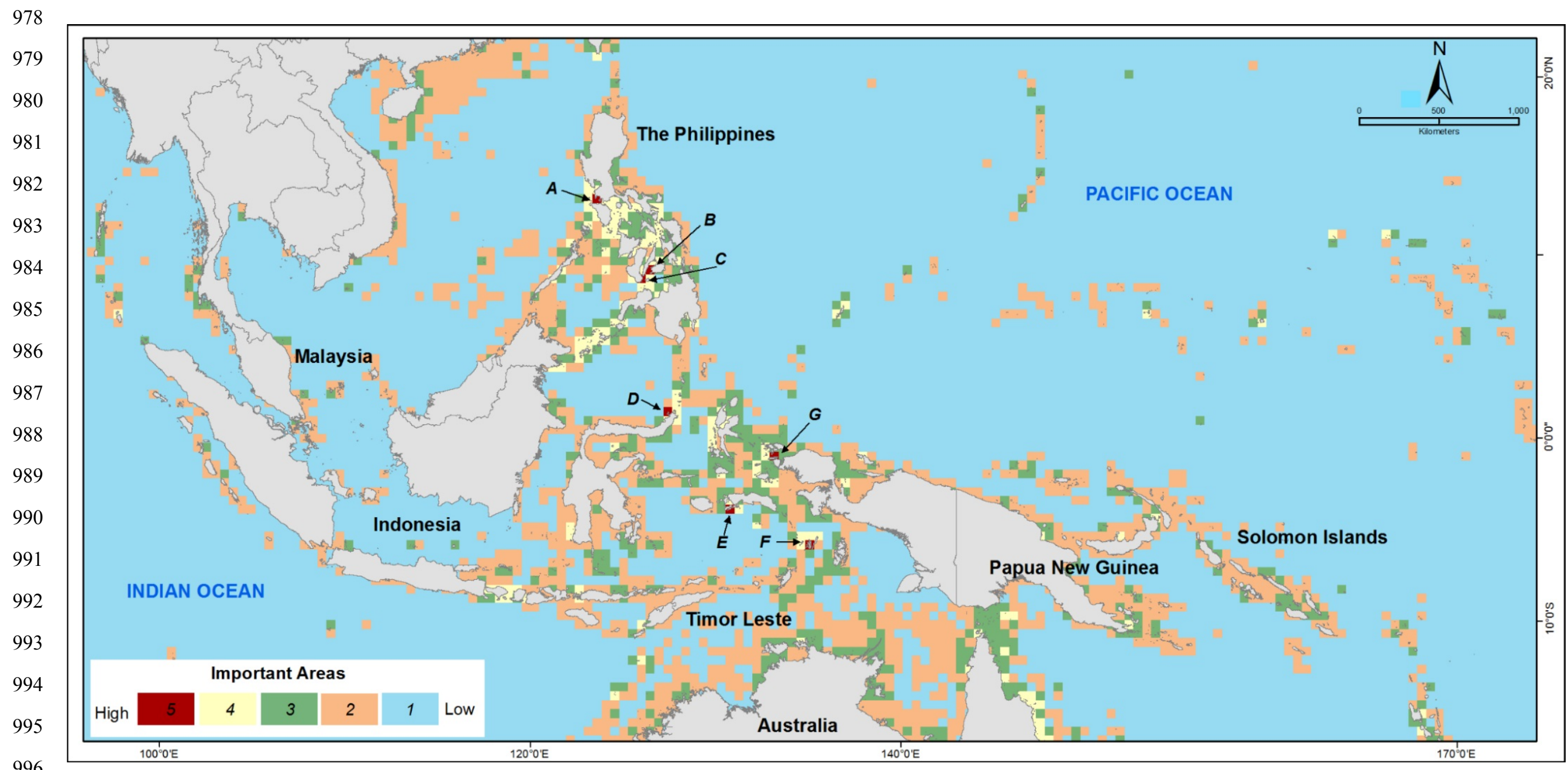

996

Figure 5. Map showing sites of biodiversity importance in the Coral Triangle, with each site defined using half-degree cells. Analysed based on unweighted sum of biodiversity score derived from five ecological criteria. The cells were ranked into five equal interval class to allow unbiased comparisons between criteria and prioritization scheme, from high to low biodiversity values: Class 5 (red), 4 (yellow), 3 (green), 2 (light brown) and 1 (light blue). The most significant sites inluded: (A) Verde Island Passage (between Luzon and Mindoro Island), (B) Negros Island, (C) Cebu Island, (D) Northern tip of Sulawesi, (E ) Ambon Island, (F) Kei Islands, and (G) Raja Ampat Archipelago of Indonesian Papua. 
Table 1. Previous studies on MPA design, biodiversity patterns and conservation prioritization in the Coral Triangle.

\begin{tabular}{|c|c|c|c|c|c|}
\hline Study & Objective & Criteria & $\begin{array}{c}\text { Geographic } \\
\text { scope }\end{array}$ & Methods & Data Used \\
\hline Hoeksema (2007) & $\begin{array}{l}\text { Identifying the } \\
\text { centre of } \\
\text { marine } \\
\text { biodiversity }\end{array}$ & Species diversity & Coral Triangle & Review & $\begin{array}{l}\text { Pelagic species, } \\
\text { marine plants, } \\
\text { molluscs } \\
\text { arthropods, fishes, } \\
\text { foraminifera, stony } \\
\text { corals, and } \\
\text { mushroom coral } \\
\text { (fungiidae) }\end{array}$ \\
\hline Allen (2008) & $\begin{array}{l}\text { Identifying } \\
\text { conservation } \\
\text { hotspots }\end{array}$ & $\begin{array}{l}\text { Species richness } \\
\text { and endemism }\end{array}$ & Indo-Pacific & $\begin{array}{l}\text { Species } \\
\text { distribution } \\
\text { patterns }\end{array}$ & $\begin{array}{l}\text { Coral reef fishes } \\
\text { (3919 species) }\end{array}$ \\
\hline $\begin{array}{l}\text { Green et al. } \\
(2009)\end{array}$ & $\begin{array}{l}\text { Designing a } \\
\text { network of } \\
\text { MPAs }\end{array}$ & $\begin{array}{l}\text { Biophysics and } \\
\text { socio-economic } \\
\text { characteristics }\end{array}$ & $\begin{array}{l}\text { Kimbe Bay } \\
\text { (Papua New } \\
\text { Guinea) }\end{array}$ & $\begin{array}{l}\text { Conservation } \\
\text { priorities }\end{array}$ & $\begin{array}{l}\text { Coral reef, reef- } \\
\text { fishes, seagrass, } \\
\text { mangroves, fish } \\
\text { spawning areas, } \\
\text { turtle nesting sites, } \\
\text { seabirds, and } \\
\text { seamounts }\end{array}$ \\
\hline $\begin{array}{l}\text { Ambal et al. } \\
(2012)\end{array}$ & $\begin{array}{l}\text { Identifying key } \\
\text { biodiversity } \\
\text { areas }\end{array}$ & $\begin{array}{l}\text { Vulnerability and } \\
\text { irreplaceability } \\
\text { of the habitat of } \\
\text { globally } \\
\text { important species }\end{array}$ & The Philippines & $\begin{array}{l}\text { Conservation } \\
\text { priorities }\end{array}$ & $\begin{array}{l}\text { Seaweeds, } \\
\text { seagrasses, corals, } \\
\text { molluscs, } \\
\text { elasmobranchs, reef } \\
\text { fishes, marine } \\
\text { turtles, seabirds, and } \\
\text { marine mammals } \\
\text { (855 species) }\end{array}$ \\
\hline $\begin{array}{l}\text { Huffard et al. } \\
\text { (2012) }\end{array}$ & $\begin{array}{l}\text { Defining } \\
\text { geographic } \\
\text { priorities for } \\
\text { marine } \\
\text { biodiversity } \\
\text { conservation }\end{array}$ & $\begin{array}{l}\text { Species richness, } \\
\text { endemism, } \\
\text { aggregation sites, } \\
\text { taxonomic } \\
\text { uniqueness }\end{array}$ & Indonesia & $\begin{array}{l}\text { Prioritization } \\
\text { exercise } \\
\text { through expert } \\
\text { opinion }\end{array}$ & $\begin{array}{l}\text { Corals, mangroves, } \\
\text { seagrasses, coral reef } \\
\text { fishes, stomatopods, } \\
\text { crustaceans, sea } \\
\text { turtles, cetaceans, } \\
\text { seabirds, dugongs, } \\
\text { and marine } \\
\text { population genetic } \\
\text { data ( } 25 \text { marine taxa) }\end{array}$ \\
\hline $\begin{array}{l}\text { Green et al. } \\
(2014)\end{array}$ & $\begin{array}{l}\text { Developing } \\
\text { guidelines to } \\
\text { design marine } \\
\text { reserves }\end{array}$ & $\begin{array}{l}\text { Ecological } \\
\text { considerations }\end{array}$ & Coral Triangle & Review & $\begin{array}{l}\text { Criteria for fisheries } \\
\text { management, } \\
\text { biodiversity } \\
\text { conservation, and } \\
\text { climate change } \\
\text { adaptation }\end{array}$ \\
\hline $\begin{array}{l}\text { Beger et al. } \\
(2015)\end{array}$ & $\begin{array}{l}\text { Developing } \\
\text { approaches to } \\
\text { conservation } \\
\text { priorities }\end{array}$ & $\begin{array}{l}\text { Representation, } \\
\text { critical and } \\
\text { important } \\
\text { habitat, } \\
\text { threatened } \\
\text { species, } \\
\text { connectivity, } \\
\text { climate change }\end{array}$ & Coral Triangle & $\begin{array}{l}\text { Quantitative } \\
\text { conservation } \\
\text { prioritization }\end{array}$ & $\begin{array}{l}\text { Marine habitats } \\
\text { (coral, mangroves), } \\
\text { groupers, sea turtles, } \\
\text { coral trout and sea } \\
\text { cucumbers }\end{array}$ \\
\hline
\end{tabular}


Table 2. Data used in this study.

\begin{tabular}{|c|c|c|}
\hline Data layer & Feature & References \\
\hline \multicolumn{3}{|l|}{ Boundary } \\
\hline Economic exclusive zone & Polyline (CT Countries) & VLIZ (2014) \\
\hline Country administrative & Polyline (CT Countries) & VLIZ (2014) \\
\hline $\begin{array}{l}\text { Coral Triangle Scientific } \\
\text { boundary }\end{array}$ & Polygon & Veron et al. (2009) \\
\hline \multicolumn{3}{|l|}{ Fragile and sensitive habitat } \\
\hline Coral reef & Coral reef distribution & $\begin{array}{l}\text { IMaRS-USF. \& IRD. (2005); } \\
\text { UNEP-WCMC et al. (2010) }\end{array}$ \\
\hline Mangrove & Mangrove distribution & Giri et al. $(2011 \mathrm{a}, \mathrm{b})$ \\
\hline Seagrass & Seagrass distribution & $\begin{array}{l}\text { UNEP-WCMC \& Short } \\
\text { (2005) }\end{array}$ \\
\hline \multicolumn{3}{|l|}{ Biological diversity } \\
\hline Species ranges & 10,672 species of 14 taxa & Kaschner et al. (2016) \\
\hline Species occurrence & 19,251 species of 14 taxa & OBIS (2015) \\
\hline \multicolumn{3}{|c|}{ Species of conservation concern } \\
\hline Species occurrence & $\begin{array}{l}\text { Bony fish, anthozoans, } \\
\text { elasmobranchs, mammals, and } \\
\text { molluscs; } \\
48,659 \text { records; } 834 \text { species }\end{array}$ & $\begin{array}{l}\text { OBIS (2015); Froese \& } \\
\text { Pauly (2016) }\end{array}$ \\
\hline \multicolumn{3}{|l|}{ Restricted range species } \\
\hline $\begin{array}{l}\text { Endemic reef fishes } \\
\text { distribution }\end{array}$ & 373 species & $\begin{array}{l}\text { Allen (2008); Allen \& } \\
\text { Erdmann (2013) }\end{array}$ \\
\hline \multicolumn{3}{|c|}{ Areas of importance for particular life history stages } \\
\hline Sea turtle & $\begin{array}{l}\text { Nesting sites and migratory } \\
\text { route of } \\
6 \text { species }(2,055 \text { records })\end{array}$ & $\begin{array}{l}\text { MoF-MoMAF (2010); OBIS } \\
(2015)\end{array}$ \\
\hline \multicolumn{3}{|c|}{ Marine environment datasets } \\
\hline Abiotic data & $\begin{array}{l}16 \text { environmental layers of } \\
\text { physical, biochemical } \\
\text { parameters including nutrients. }\end{array}$ & Basher et al. (2014) \\
\hline \multicolumn{3}{|c|}{ Marine Protected Areas (MPA) } \\
\hline MPA boundary & Coverage of 678 MPAs. & $\begin{array}{l}\text { IUCN \& UNEP-WCMC, } \\
\text { 2016; Cros et al., 2014; } \\
\text { MoF-MoMAF, 2010; } \\
\text { MoMAF, 2016. }\end{array}$ \\
\hline
\end{tabular}


1001

1002

1003

1004

1005

Table 3. Proportion of modelled geographic ranges of 14 taxonomic groups of marine species within the CT in half-degree cells.

\begin{tabular}{|c|c|c|c|c|c|c|}
\hline \multirow[t]{2}{*}{ Taxonomic Group } & \multirow[b]{2}{*}{$\begin{array}{c}\text { Total } \\
\text { number of } \\
\text { known } \\
\text { species in } \\
\text { world* }\end{array}$} & \multicolumn{2}{|c|}{ Species Analyzed } & \multirow{2}{*}{$\begin{array}{l}\text { Occurrence } \\
\text { frequency } \\
(\%)\end{array}$} & \multicolumn{2}{|c|}{ Species per cells } \\
\hline & & Number & $\begin{array}{c}\text { Proportion } \\
\text { of global total } \\
(\%)\end{array}$ & & Maximum & Mean \\
\hline $\begin{array}{l}\text { Actinopterygii } \\
\text { Bony fishes }\end{array}$ & 16,997 & 5,683 & 33 & 91 & 3,329 & 581 \\
\hline $\begin{array}{l}\text { Anthozoa } \\
\text { Corals and anemones }\end{array}$ & 7,028 & 570 & 8 & 30 & 397 & 52 \\
\hline $\begin{array}{l}\text { Appendicularia } \\
\text { Tunicates }\end{array}$ & 67 & 11 & 16 & 27 & 7 & 1 \\
\hline $\begin{array}{l}\text { Asteroidea } \\
\text { Starfish, sea stars }\end{array}$ & 1,839 & 125 & 7 & 30 & 84 & 9 \\
\hline $\begin{array}{l}\text { Crinoidea } \\
\text { Feather stars and sea lilies }\end{array}$ & 659 & 64 & 10 & 25 & 43 & 4 \\
\hline $\begin{array}{l}\text { Elasmobranchii } \\
\text { Sharks, rays, sawfish }\end{array}$ & 1,146 & 334 & 29 & 87 & 152 & 28 \\
\hline $\begin{array}{l}\text { Holocephali } \\
\text { Chimaera }\end{array}$ & 52 & 15 & 29 & 17 & 4 & 1 \\
\hline $\begin{array}{l}\text { Holothuridea } \\
\text { Sea cucumbers }\end{array}$ & 1,693 & 67 & 4 & 25 & 35 & 5 \\
\hline $\begin{array}{l}\text { Mammalia } \\
\text { Whales, dolphins, dugongs }\end{array}$ & 135 & 35 & 26 & 89 & 25 & 7 \\
\hline $\begin{array}{l}\text { Malacostraca } \\
\text { Lobsters, crabs, shrimps, } \\
\text { crayfish }\end{array}$ & 32,189 & 1,624 & 5 & 90 & 458 & 64 \\
\hline $\begin{array}{l}\text { Maxillopoda } \\
\text { Barnacles, Copepods }\end{array}$ & 13,179 & 159 & 1 & 61 & 45 & 7 \\
\hline $\begin{array}{l}\text { Polychaeta } \\
\text { Worms }\end{array}$ & 11,692 & 181 & 2 & 36 & 50 & 4 \\
\hline $\begin{array}{l}\text { Reptilia } \\
\text { Turtles and sea-snakes }\end{array}$ & 110 & 28 & 25 & 49 & 17 & 3 \\
\hline $\begin{array}{l}\text { Mollusca } \\
\text { Gastropods, cephalopods and } \\
\text { bivalves }\end{array}$ & 46,537 & 1,775 & 4 & 69 & 950 & 128 \\
\hline Total & 133,323 & 10,672 & 8 & & & \\
\hline
\end{tabular}

* Horton et al. (2016).

Table 4. Number of species of conservation concern based on the IUCN Red List, CITES and national regulations of Indonesia, Malaysia and the Philippines.

\begin{tabular}{|c|c|c|c|c|c|c|}
\hline \multirow[t]{2}{*}{ Category } & \multicolumn{5}{|c|}{ Number of Species } & \multirow[t]{2}{*}{ Total } \\
\hline & $\begin{array}{r}\text { Bony } \\
\text { fishes }\end{array}$ & Anthozoa & $\begin{array}{l}\text { Elasmo- } \\
\text { branchs }\end{array}$ & Mammals & Molluses & \\
\hline \multirow{2}{*}{\multicolumn{7}{|c|}{$\begin{array}{l}\text { IUCN Red List } \\
\text { Critically }\end{array}$}} \\
\hline & & & & & & \\
\hline Endangered & 1 & 3 & 12 & 1 & & 17 \\
\hline Vulnerable & 7 & 103 & 52 & 4 & 1 & 167 \\
\hline \multicolumn{7}{|l|}{ CITES } \\
\hline Appendix I & - & - & 7 & 9 & - & 16 \\
\hline Appendix II & 19 & 707 & 9 & 16 & 6 & 757 \\
\hline \multicolumn{7}{|l|}{ National } \\
\hline Protected & - & 11 & 7 & 23 & 10 & 51 \\
\hline Total * & 19 & 707 & 73 & 25 & 10 & \\
\hline
\end{tabular}


1003

1004

1005

1006

1007

1008

1009

Table 5. Spearman's rank correlation coefficients between criteria. The coefficients indicated the strength and statistical association between criteria in each 0.5 -degree cells. All of the values are statistically significant at $P<0.01(\mathrm{n}=13,360)$.

\begin{tabular}{l|ccccc}
\hline \multicolumn{1}{c|}{ Criteria } & $\begin{array}{c}\text { Species } \\
\text { richness } \\
\text { (ranges) }\end{array}$ & $\begin{array}{c}\text { Species } \\
\text { richness } \\
\text { (occurrence) }\end{array}$ & $\begin{array}{c}\text { Species of } \\
\text { conservation } \\
\text { concern }\end{array}$ & $\begin{array}{c}\text { Restricted- } \\
\text { range reef } \\
\text { fishes }\end{array}$ & $\begin{array}{c}\text { Sea turtle } \\
\text { important } \\
\text { areas }\end{array}$ \\
\hline Biogenic habitat & 0.57 & 0.30 & 0.24 & 0.39 & 0.09 \\
Species richness (ranges) & & 0.24 & 0.35 & 0.49 & 0.23 \\
$\begin{array}{l}\text { Species richness (occurrence) } \\
\text { Species of conservation concern }\end{array}$ & & & 0.37 & 0.08 & 0.16 \\
Restricted-range reef fishes & & & & 0.23 & 0.15 \\
\hline
\end{tabular}

Table 6. Spearman's rank correlation coefficients between each criterion and the environmental variables. The coefficient strength ranges from negative (dark to light red) to positive (light to dark blue). $P<0.05(*) ;<0.01(* *) ; n=13,360$. Depth was denoted in negative values (e.g., - $100 \mathrm{~m})$.

\begin{tabular}{|c|c|c|c|c|c|c|}
\hline $\begin{array}{c}\text { Environmental } \\
\text { variable }\end{array}$ & $\begin{array}{c}\text { Biogenic } \\
\text { habitat }\end{array}$ & $\begin{array}{c}\text { Species } \\
\text { richness } \\
\text { from } \\
\text { ranges } \\
\end{array}$ & $\begin{array}{c}\text { Species } \\
\text { richness } \\
\text { from } \\
\text { occurrence } \\
\end{array}$ & $\begin{array}{c}\text { Species of } \\
\text { conservation } \\
\text { concern }\end{array}$ & $\begin{array}{l}\text { Restricted- } \\
\text { range reef } \\
\quad \text { fishes }\end{array}$ & $\begin{array}{l}\text { Sea turtle } \\
\text { important } \\
\quad \text { areas }\end{array}$ \\
\hline Depth & $0.44^{* *}$ & $0.32^{* *}$ & $0.24^{* *}$ & $0.14^{* *}$ & $0.2^{* *}$ & 0.01 \\
\hline Slope & $-0.14^{* *}$ & $0.1^{* *}$ & $-0.12^{* *}$ & -0.01 & $0.14^{* *}$ & $0.07^{* *}$ \\
\hline Land distance & $-0.48^{* *}$ & $-0.28^{* *}$ & $-0.19^{* *}$ & $-0.14^{* *}$ & $-0.37^{* *}$ & $0.04^{* *}$ \\
\hline Temperature (mean) & $0.03^{* *}$ & $0.34^{* *}$ & $-0.03^{* *}$ & $0.17^{* *}$ & $0.22^{* *}$ & $0.22^{* *}$ \\
\hline Surface current & $0.11^{* *}$ & 0.04 & $0.06^{* *}$ & $-0.07^{* *}$ & -0.01 & $0.07^{* *}$ \\
\hline Salinity & $-0.24^{* *}$ & -0.01 & 0.01 & $0.06^{* *}$ & $-0.08^{* *}$ & $0.09^{* *}$ \\
\hline Wind speed & $-0.31^{* *}$ & $-0.15^{* *}$ & $-0.04^{* *}$ & $-0.15^{* *}$ & $-0.27^{* *}$ & $0.02^{*}$ \\
\hline Tide (average) & $-0.08^{* *}$ & $0.31^{* *}$ & $0.10^{* *}$ & $0.19^{* *}$ & $0.06^{* *}$ & $0.22^{* *}$ \\
\hline PrimarypProductivity & $0.18^{* *}$ & $0.71^{* *}$ & $0.23^{* *}$ & $0.31^{* *}$ & $0.30^{* *}$ & $0.21^{* *}$ \\
\hline$P A R$ & $-0.10^{* *}$ & $0.11^{* *}$ & $0.43^{* *}$ & $0.19^{* *}$ & $0.03^{* *}$ & $0.15^{* *}$ \\
\hline$p H$ & $-0.2^{* *}$ & $0.02^{*}$ & -0.06 & 0.04 & -0.14 & 0.08 \\
\hline Chlorophyll -A (mean) & $0.28^{* *}$ & $0.14^{* *}$ & $0.12^{* *}$ & $0.05^{* *}$ & 0.01 & $0.02^{*}$ \\
\hline Dissolved $\mathrm{O}_{2}$ & $-0.14^{* *}$ & $0.3 * *$ & -0.01 & 0.11 & 0.03 & 0.2 \\
\hline Nitrate & $-0.13^{* *}$ & $-0.16^{* *}$ & $-0.09^{* *}$ & $-0.07^{* *}$ & $-0.19^{* *}$ & $-0.14^{* *}$ \\
\hline Silicate & $0.03^{* *}$ & $0.42^{* *}$ & $0.09^{* *}$ & $0.14^{* *}$ & $0.05^{* *}$ & $0.13^{* *}$ \\
\hline Calcite & $-0.29^{* *}$ & 0.01 & $-0.19^{* *}$ & $-0.03^{* *}$ & 0.01 & $0.04^{* *}$ \\
\hline
\end{tabular}

